\title{
Methane vertical profiles over the Indian subcontinent derived from the GOSAT/TANSO-FTS thermal infrared sensor
}

\author{
Dmitry A. Belikov ${ }^{1}$, Naoko Saitoh ${ }^{1}$, Prabir K. Patra ${ }^{2,1}$, and Naveen Chandra ${ }^{2}$ \\ ${ }^{1}$ Center for Environmental Remote Sensing, Chiba University, Chiba, 263-8522, Japan \\ $5 \quad{ }^{2}$ Research Institute for Global Change (RIGC), Japan Agency for Marine-Earth Science and Technology (JAMSTEC), \\ Yokohama, 236-0001, Japan
}

Correspondence to: Dmitry A. Belikov (d.belikov@chiba-u.jp)

10 thermal infrared (TIR) band observations by the Thermal And Near-infrared Sensor for carbon Observation-Fourier Transform MIROC4.0-based Atmospheric Chemistry Tracer Model (MIROC4-ACTM) for the period 2009-2014. This study attempts to understand the sensitivity of the vertical profile retrievals at different layers of the troposphere and lower stratosphere, arising from the averaging kernels and a priori assumptions. We stress that this is of particular importance when the satellite derived

15 products are analysed using a different ACTMs from that is used as retrieval a priori. A comparison of modeled and retrieved $\mathrm{CH}_{4}$ vertical profiles shows the 22 vertical levels of GOSAT/TANSO-FTS TIR retrievals provide critical information about transport from the top of the boundary layer to upper troposphere and lower stratosphere in a consistent manner. The mean model-GOSAT TIR $\mathrm{CH}_{4}$ mismatch is within $50 \mathrm{ppb}$, excepting $150 \mathrm{hPa}$ and upward, where the sensitivity of GOSAT/TANSOFTS TIR observations becomes very low. Convolution of the modeled profiles with GOSAT/TANSO-FTS TIR averaging kernels reduce the mismatch to below uncertainty. Distinct seasonal variations of $\mathrm{CH}_{4}$ have been observed at the upper atmospheric boundary layer $(800 \mathrm{hPa})$, free troposphere $(500 \mathrm{hPa})$, and upper troposphere $(200 \mathrm{hPa})$ levels over northern and southern regions of India corresponding to the southwesterly monsoon (July-September) and post-monsoon (OctoberDecember) seasons. Analysis of the transport and emission contributions to $\mathrm{CH}_{4}$ suggests that the $\mathrm{CH}_{4}$ seasonal cycle over the Indian subcontinent is governed by both the heterogeneous distributions of surface emissions and the influence of the global monsoon divergent wind circulations. GOSAT/TANSO-FTS TIR observations provide additional information about $\mathrm{CH}_{4}$ observations in this region compared to what is known from in situ data, which is important for improving the accuracy of emission flux optimization. Based on two emission sensitivity simulations, we suggest that the emissions of $\mathrm{CH}_{4}$ from the India region is $51.2 \pm 1.6 \mathrm{Tg} \mathrm{yr}^{-1} 1$ during the period of $2009-2014$. 


\section{Introduction}

The Asian Summer Monsoon Anticyclone (ASMA) is a dominant circulation in the Upper Troposphere and Lower Stratosphere (UTLS) in the Northern Hemisphere summer, which extends from Southeast Asia to the Middle East [Webster et al., 1998, Fleitmann et al., 2007]. The Asian monsoons may be classified into a few sub-systems, such as the South Asian Monsoon, which affects the Indian subcontinent and surrounding regions. The monsoon is associated with persistent strong convection over India and the Bay of Bengal, elevated surface heating over the Tibetan Plateau, and orographic uplifting at the southern/south-western slopes of the Himalayas, which contribute to overall ascension of boundary layer air to the upper troposphere (up to $200-100 \mathrm{hPa}$ ) [Fu et al., 2006]. The deep convection and associated circulation patterns of the monsoon provides an important pathway for polluted boundary layer air to reach UTLS [Randel and Park, 2006, Randel et al., 2010]. Then atmospheric compounds can be advected over other regions, or further uplifted in the stratosphere [Xiong et al., 2009, Patra et al., 2011, Garny and Randel, 2016]. Due to the influence of deep convection and long-range transport, the chemical tracers such as $\mathrm{CH}_{4}, \mathrm{CO}$, and ozone show sometimes extreme values [Park et al., 2004, 2008].

The South Asia region, consisting of India, Pakistan, Bangladesh, Nepal, Bhutan, and Sri Lanka, play an import part in the global $\mathrm{CH}_{4}$ budget, as the regional total emission cover $8 \%$ of about $500 \mathrm{Tg} \mathrm{CH}_{4}$ global total emissions during the 2000s [Patra et al., 2013]. The recent economic growth of India has led to a significant increase in industrial emissions [Akimoto, 2003, Ohara et al., 2007, Janssens-Maenhout et al., 2019], especial in the Indo-Gangetic Plain (IGP) encompassing northern regions of India, which is one of the most densely populated region on the globe [Kar et al., 2010]. However, there are little or no longterm measurements of $\mathrm{CH}_{4}$ and the other greenhouse gases to evaluate the inventory emissions [Ganesan et al., 2017, Lin et al., 2018, Chandra et al., 2019].

Global observations from satellite instruments can complement and extend the information available from the surface in situ and aircraft measurements to improve our knowledge of the processes controlling emission and distribution of methane, to monitor its variability on different scales. The shortwave infrared (SWIR) and thermal infrared (TIR) bands are available for measurements of $\mathrm{CH}_{4}$ from space.

Observations in the SWIR, such as those from SCIAMACHY on Envisat [Buchwitz et al., 2005, Frankenberg et al., 2011] and TANSO Fourier transform spectrometer (FTS) on GOSAT [Butz et al., 2010, Parker et al., 2011, Yoshida et al., 2013], provide information on column-averaged methane, in cloud-free conditions. SWIR measurements are limited to daytime and predominantly over land. On the other hand, $\mathrm{TIR} \mathrm{CH}_{4}$ observations provide much greater geographical and temporal coverage, and more importantly the measurements of vertical profiles allow a better understanding of the $\mathrm{CH}_{4}$ cycle over a region. The sensitivity of TIR $\mathrm{CH}_{4}$ observations is stronger in the mid to upper troposphere and relatively low near the surface, as its spectral signatures depend on thermal contrast between the atmosphere and surface [Saitoh et al., 2016, de Lange and Landgraf, 2018].

60 At present moment five nadir-viewing TIR instruments operate on orbit including Atmospheric InfraRed Sounder (AIRS), aboard Aqua, launched in 2002 [Xiong et al., 2008, Zou et al., 2016]; Infrared Atmospheric Sounding Interferometer (IASI), 
aboard Metop-A and Metop-B, launched in respectively 2006 and 2012 [Razavi et al., 2009, Crevoisier et al., 2009, 2013, Xiong et al., 2013, Siddans et al., 2017]; TANSO-FTS, aboard GOSAT, launched in 2009 [Kuze et al., 2009, 2012, Yokota et al., 2009, Saitoh et al., 2012, 2016]; Cross-track Infrared Sounder (CrIS), aboard Suomi-NPP, launched in 2011 [Han et al., 2013]; and TANSO-FTS-2, aboard GOSAT-2, launched in 2018 [Matsunaga et al., 2019].

The columnar dry-air mole fractions of methane $\left(\mathrm{XCH}_{4}\right)$ retrieved over Indian regions from SCIAMACHY shows large spatio-temporal variation closely associated with the distribution of sources like livestock population, wetland, biomass burning, oil and gas production [Kavitha and Nair, 2016]. The seasonal variation of $\mathrm{XCH}_{4}$ is controlled by agricultural activities, mainly rice cultivation as revealed by NDVI analysis [Hayashida et al., 2013]. Along with the heterogeneity in surface emissions variations of $\mathrm{XCH}_{4}$ governed by complex atmospheric transport mechanisms during the southwestern monsoon season in July-September and northeastern monsoon season in October-December as observed by GOSAT. Chandra et al. [2017] have highlighted the difficulty in interpreting the emissions from the surface by columnar $\mathrm{CH}_{4}$ measurements from SWIR spectra, without using an atmospheric chemistry-transport model. At the same time Ricaud et al. [2014] investigated the space-time variations in tropospheric $\mathrm{CH}_{4}$ over the Mediterranean Basin regions using a wide variety of datasets including GOSAT/TANSO-FTS TIR observations.

This study attempts to analyze the vertical distributions of $\mathrm{CH}_{4}$ over the Asian monsoon region. We used $\mathrm{CH}_{4}$ mixing ratios observed from GOSAT/TANSO-FTS TIR (hereafter referred as "GOSAT-TIR") and simulated by the Model for Interdisciplinary Research on Climate (MIROC, version 4.0) [Watanabe et al., 2008] based atmospheric chemistry transport models (ACTM) [Patra et al., 2018] referred to as "MIROC4-ACTM". We aim to understand relative contributions of surface emissions and transport in the formation of $\mathrm{CH}_{4}$ seasonal cycles over different parts of India and the surrounding oceans. The paper is structured as follows. In Section 2, we briefly describe the spaceborne instrument GOSAT-TIR and vertical profiles retrievals of $\mathrm{CH}_{4}$, the MIROC4-ACTM simulation setup, the study domain and data processing. The meteorology and climatology of $\mathrm{CH}_{4}$ inferred from the different data sets over the study domain, variability of $\mathrm{CH}_{4}$ vertical profiles and the impact of the Asian Monsoon Anticyclone to the distribution of the tropospheric $\mathrm{CH}_{4}$ are discussed in Section 3. Major conclusions are given in Section 4.

\section{Method}

\subsection{GOSAT data}

GOSAT is the first satellite dedicated to global observations of greenhouse gases $\mathrm{CO}_{2}$ and $\mathrm{CH}_{4}$ from space [Yokota et al., 2009]. After the launch on 23 January 2009, GOSAT has performed observations on a $666 \mathrm{~km}$ sun-synchronous orbit with a

90 3-day revisit cycle, a 12-day operation cycle, and the local solar time of 13:00 $\pm 15 \mathrm{~min}$.

The Thermal and Near-infrared Sensor for Carbon Observation Fourier Transform Spectrometer (TANSO-FTS) on board GOSAT detects short-wavelength infrared (SWIR) light reflected from the earth's surface, along with the thermal infrared (TIR) radiation emitted from the ground and atmosphere [Kuze et al., 2009, 2012]. As a result, from these spectral bands, 
GOSAT/TANSO-FTS can simultaneously observe $\mathrm{CH}_{4}$ column averaged dry-air mole fractions and $\mathrm{CH}_{4}$ profiles in the same

field of view, corresponding to a nadir footprint diameter of $10.5 \mathrm{~km}$. The a priori profiles used in the $\mathrm{CH}_{4}$ retrieval are provided by the National Institute for Environmental Studies (NIES) transport model [Saeki et al., 2013]. Temperature and water vapor profiles necessary for the retrieval are provided by the Japan Meteorological Agency Grid Point Values (JMA-GPV) dataset.

The first retrieval version of the GOSAT-TIR $\mathrm{CH}_{4}$ product (V00.01) and its validation analysis showed the total column values of $\mathrm{CH}_{4}\left(\mathrm{XCH}_{4}\right)$ based on the GOSAT-TIR $\mathrm{CH}_{4}$ profiles agreed within $0.5 \%$ of the aircraft $\mathrm{XCH}_{4}$ values over the tropical ocean [Saitoh et al., 2012]. Holl et al. [2016] did comparisons among $\mathrm{CH}_{4}$ data from ACE-FTS, ground based FTS, and the current released version of GOSAT-TIR ( ) in the Canadian high Arctic, although GOSAT-TIR $\mathrm{CH}_{4}$ measurement information content is too low for a true profile retrieval because of the low thermal contrast and the low signal-to-noise ratio there. Global comparisons with AIRS retrievals reveal good agreement at 300-600 hPa, where both AIRS and GOSAT-TIR $\mathrm{CH}_{4}$ have peak sensitivities [Zou et al., 2016]. Mean mismatch in $\mathrm{CH}_{4}$ (GOSAT-AIRS) were 10.3-31.8 and -16.2 25.7 ppbv for the levels of 300 and $600 \mathrm{hPa}$, respectively. Comparison of the $\mathrm{XCH}_{4}$ shows that GOSAT-TIR agrees with AIRS to within $1 \%$ in the midlatitude regions of the Southern Hemisphere and in the tropics. However, disagreement increases to $\sim 1-2 \%$ in the mid to high latitudes [Zou et al., 2016]. Olsen et al. [2017] performed global comparisons of GOSAT-TIR vertical profiles to the Canadian Space Agency's Atmospheric Chemistry Experiment FTS (ACE-FTS) on SCISAT (version 3.5) and the European Space Agency's Michelson Interferometer for Passive Atmospheric Sounding (MIPAS) on Envisat, as well as 16 ground stations

110 with the Network for the Detection of Atmospheric Composition Change (NDACC).

In the overlapping altitude ranges of the three satellite data products there is a small, but consistent, positive bias of around $20 \mathrm{ppbv}$, or $1 \%$ in GOSAT-TIR $\mathrm{CH}_{4}$ data. In the upper troposphere, good agreement between TANSO-FTS and NDACC was found, without a bias. In a more recent comparison, the average bias in $\mathrm{CH}_{4}$ profile retrieved from GOSAT-TIR spectra with a spectral correction scheme is less than $2 \%$ over the full altitude range, when compared with data from the Monitoring

115 Atmospheric Composition and Climate (MACC) scaled to the total column measurements of the Total Carbon Column Observing Network (TCCON) [de Lange and Landgraf, 2018].

This study uses the GOSAT-TIR $\mathrm{CH}_{4}$ product, which is released for the period from April 23, 2009, through May 24, 2014. The number of vertical grid layers of the GOSAT-TIR $\mathrm{CH}_{4}$ product is 22 from the surface to $0.1 \mathrm{hPa}$.

\subsection{MIROC4-ACTM simulations}

The measurements are compared to results of simulations by the MIROC4-ACTM chemical tracer simulation [Watanabe et al., 2008, Patra et al., 2018]. The MIROC4-ACTM runs at a horizontal resolution of T42 spectral truncations $(\approx 2.8 \times 2.8)$ with 67 sigma-pressure vertical levels. The MIROC4-ACTM simulated horizontal winds (U and V) and temperature (T) are nudged to the Japan Meteorological Agency reanalysis fields (JRA-55) at all the vertical levels [Kobayashi et al., 2015]. The model uses an optimal $\mathrm{OH}$ field based on a scaled version of the seasonally varying $\mathrm{OH}$ field [Patra et al., 2014]. 
Two simulations were performed using combinations of inverted fluxes based on the following a priori emission scenarios prepared on a monthly basis by combining the emissions from all anthropogenic and natural sectors, and by subtracting the surface sinks due to bacterial consumption in the soil [Chandra et al., 2020]:

1. Flux $\mathrm{x}_{\mathrm{Cao}}$ : EDGAR + GFED + other + VISIT wetland (Cao scheme [Cao et al., 1996]).

2. Fluxwh: EDGAR + GFED + other + VISIT wetland (WH scheme [Walter et al.,2001]).

130 Here, EDGAR (the Emission Database for Global Atmospheric Research, version 4.3.2 inventory [Janssens-Maenhout et al., 2019]) provides the anthropogenic emissions for individual sector at the spatial resolution of $0.1^{\circ} \times 0.1^{\circ}$ on an annual basis for the period 1970-2012. The growth rate for 2011-2012 has been used to interpolate the inventory emissions for 2013-2017. GFED (Global Fire Database version 4s [van der Werf et al., 2017]) is monthly emissions for biomass burning. The other emissions (including ocean, termites, mud volcano etc.) are taken from TransCom-CH4 inter-comparison experiment [Patra et al., 2011]. VISIT (Vegetation Integrated Simulator of Trace gases [Ito, 2019, Ito et al., 2019]) is a process-based model of the terrestrial biogeochemical cycle, which is used to estimate the wetland and rice emissions on monthly basis using two different schemes developed by Cao et al. [1996] and Walter et al. [2001], referred by "ACTM ${ }_{\text {Cao }}$ " and "ACTM ${ }_{W H}$ " scheme, respectively.

\subsection{Data processing}

The MIROC4-ACTM data were collocated to the GOSAT-TIR observation points. The criteria for the collocation are the nearest model grid cell in space, and the nearest hour in time. For vertical profile comparison, the MIROC4-ACTM data were interpolated on the retrieval pressure levels of the GOSAT-TIR product, i.e. from 67 to 22 levels.

\subsection{Averaging kernels and the retrieval sensitivity}

The averaging kernels (AK) are defined to provide a simple characterization of the relationship between the retrieval and the true state. The retrieval sensitivity can be obtained from the sum of the columns of the averaging kernel matrix, which is also referred to as "the area of the averaging kernel" [Rodgers, 2000].

Along with "raw" model simulation results $\left(\mathrm{ACTM}_{\mathrm{Cao}, \mathrm{WH}}\right)$ we analysed $\left(\mathrm{ACTM}_{\mathrm{Cao}, \mathrm{WH}}^{\mathrm{AK}}\right)$ profiles convoluted with retrieval a priori and the GOSAT-TIR $\mathrm{CH}_{4}$ averaging kernel matrix using the following vector equation [Rodgers, 2000, Saitoh et al., 2012]:

$$
\mathbf{X}_{\mathrm{ACTM}_{\mathrm{CaO}, \mathrm{WH}}^{\mathrm{AK}}}=\mathbf{X}_{\text {a priori }}+\mathbf{A}\left(\mathbf{X}_{\mathrm{ACTM}_{\mathrm{Cao}, \mathrm{WH}}}-\mathbf{X}_{\text {a priori }}\right)
$$

Here, $\mathbf{A}$ is an averaging kernel matrix, $\mathbf{X}_{\text {apriori }}$ represent a vector of a priori vertical profile, $\mathbf{X}_{\mathrm{ACTM}} \mathrm{Cao,WH}_{\text {, }}$ and $\mathbf{X}_{\mathrm{ACTM}}^{\mathrm{AK}} \mathrm{Cao,WH}_{\mathrm{WH}}$ are vectors of "raw" and convoluted model simulated profiles, respectively.

\subsection{Study domain}

This work follows the setup described by [Chandra et al., 2017] and uses 10 regions (Fig. 1) which are characterized by different $\mathrm{CH}_{4}$ emission and meteorological conditions. The Indian landmass was partitioned into eight sub-regions surrounding 

(BB), Western India (WI), Central India (CI), Eastern India (EI), Arid India (AI), Western IGP (WIGP), Eastern IGP (EIGP), and Northeast India (NEI).

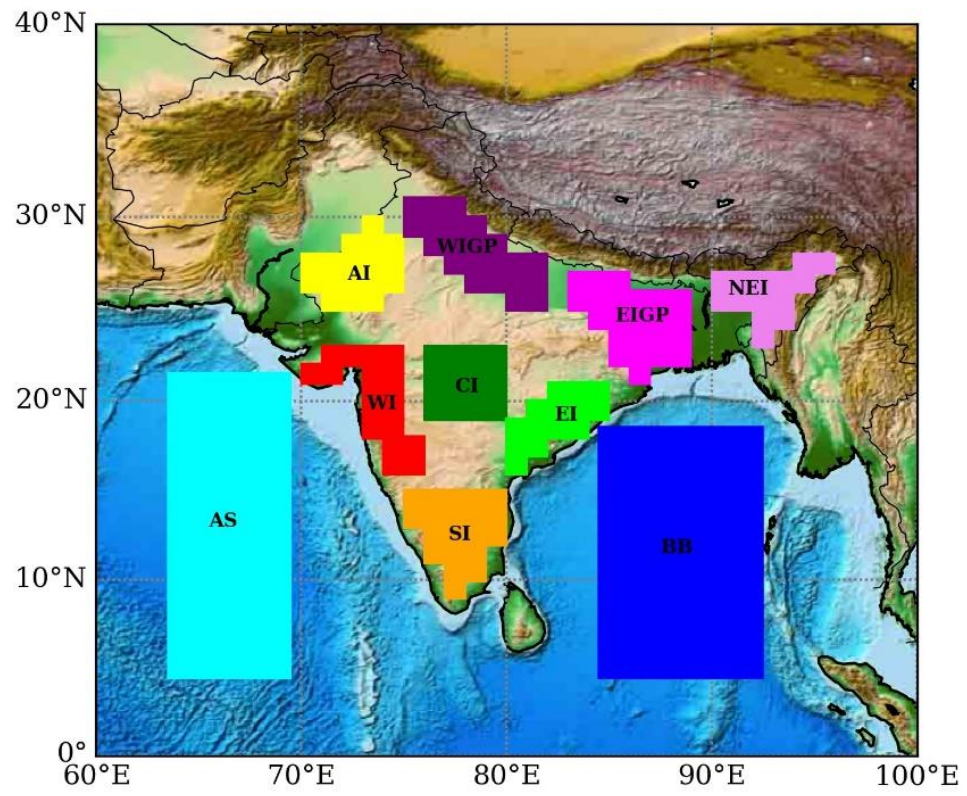

Figure 1: The map of the regional divisions for the analysis, as defined by [Chandra et al., 2017]. The Indian regions from 160 Southwest to Northeast are following: the Arabian Sea (AS), Southern India (SI), the Bay of Bengal (BB), Western India (WI), Central India (CI), Eastern India (EI), Arid India (AI), Western IGP (WIGP), Eastern IGP (EIGP), and Northeast India (NEI). Here and after all countries' borders are plotted using maps build in the matplotlib basemap toolkit (v. 1.2.0) in Python.

\section{Results and discussion}

\subsection{Atmospheric conditions controlling the spatial distribution of methane}

Key-components of the climatology in the Indian Ocean and the surrounding areas are the annual migration of the Intertropical Convergence Zone (ITCZ) and seasonal development of the monsoon winds [Findlater, 1969, Webster et al., 1998, Fleitmann et al., 2007]. In boreal spring the ITCZ migrates northward across the Indian Ocean and reaches its northernmost position at approximately $35 \mathrm{~N}$ during summer. A strong pressure gradient between the low-pressure zone over the Tibetan Plateau and a high-pressure zone over the Southern Indian Ocean generates a strong near surface monsoonal airflow from July to September (Fig. 2c1-c3).

In autumn the ITCZ then retreats southward and reaches its southernmost position at approximately $25 \mathrm{~S}$ in January. The reversed pressure gradient during the winter months generates the moderate and dry northeast monsoon (Fig. 2d1-d3). Using Moderate Resolution Imaging Spectroradiometer (MODIS) onboard Terra and Aqua satellites Devasthale and Fueglistaler [2010] showed that a significant fraction of high opaque clouds reaches and penetrates the tropical tropopause layer during 
https://doi.org/10.5194/amt-2020-101

Preprint. Discussion started: 13 July 2020

(c) Author(s) 2020. CC BY 4.0 License.

\author{
Atmospheric \\ Measurement \\ Techniques \\ Discussions
}

Surface pressure, $\mathrm{hPa}$
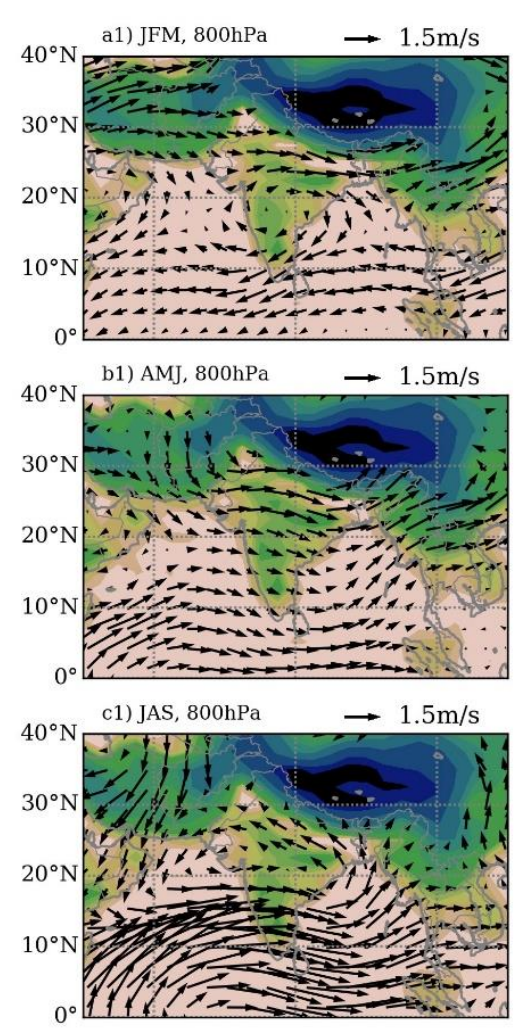

d1) OND, $800 \mathrm{hPa}$

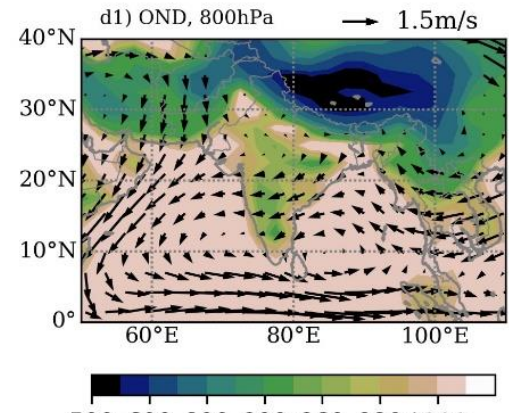

5006008009009609801000
OLR, W/m $\mathrm{m}^{2}$
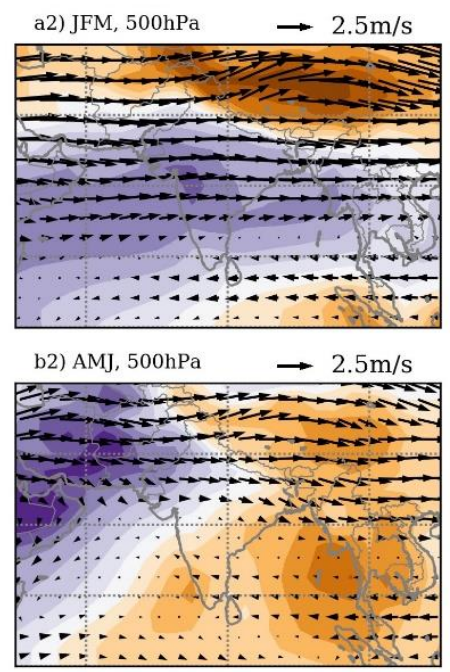

c2) JAS, 500hPa

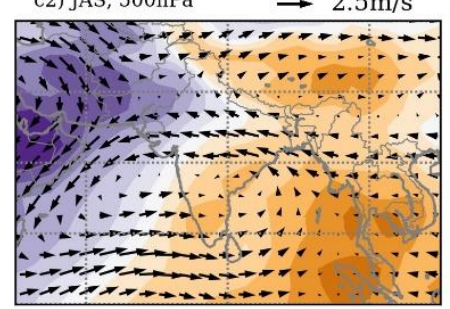

d2) OND, $500 \mathrm{hPa}$

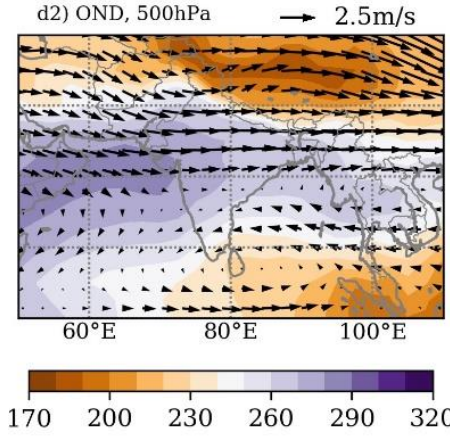

Cloud top pressure, hPa
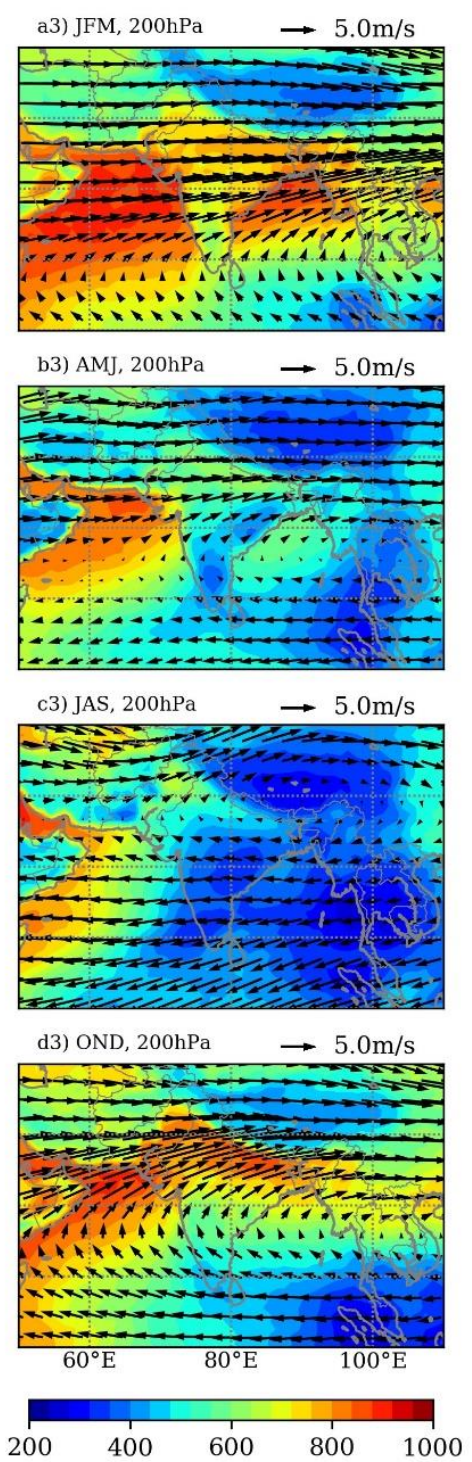

Figure 2: The wind speed vector fields for the JFM (panels a1-a3), AMJ (b1-b3), JAS (c1-c3), and OND (d1-d3) periods of 2010 from the MIROC4-ACTM dataset. Please note different vector scale for the levels of 800 (panels a1-d1), 500 (a2-d2), and 200 hPa (a3-d3) respectively. At the background: left panels (a1-d1) show monthly surface pressure (0.9950 sigma level) from the National Centers for Environmental Prediction (NCEP) reanalysis averaged for 1981-2010 (http://www.esrl.noaa.gov/psd/data/

180 gridded/data.ncep.reanalysis.derived.html), central panels (a2-d2) show monthly long term mean interpolated outgoing longwave radiation (OLR) from National Oceanic and Atmospheric Administration (NOAA) averaged for 1981-2010 (https://www.esrl. noaa.gov/psd/data/gridded/data.interp_OLR.html), the right panels (a3-d3) show seasonally averaged (for 2009-2014) daily mean cloud top pressure (hPa) from the level-3 MODIS atmosphere daily global product (v6.1) downloaded from the Giovanni online data system [Acker and Leptoukh, 2007].

185 active monsoon conditions Fig. 2c3. The overall frequency of convective clouds (reaching at least $200 \mathrm{hPa}$ ) is higher in July and August. Most of the deep convection occurs over the Bay of Bengal and central northeast India Bergman et al. [2013]. 
They suggested that very deep convection over the Tibetan plateau is comparatively weak, and may play only a secondary role in troposphere-to-stratosphere transport.

\subsection{GOSAT-TIR $\mathrm{CH}_{4}$ profile properties}

The observation by GOSAT-TIR band enables us to analyse the vertical structure of atmospheric $\mathrm{CH}_{4}$. This band has relatively high spectral resolution of $\sim 0.2 \mathrm{~cm}^{-1}$ and provides $\mathrm{CH}_{4}$ vertical profiles in 22 layers. The degrees of freedom of signal for $\mathrm{CH}_{4}$ observation by GOSAT-TIR band (V1 algorithm version) is around 1 over low-latitude part of India. Figure 3 suggests that the GOSAT-TIR spectra are sensitive to the CH4 concentrations in the height range of $900 \mathrm{hPa}$ to $30 \mathrm{hPa}$. The spectra sensitivity does not change significantly between the different part of our analysis region, as seen from Fig. 3.
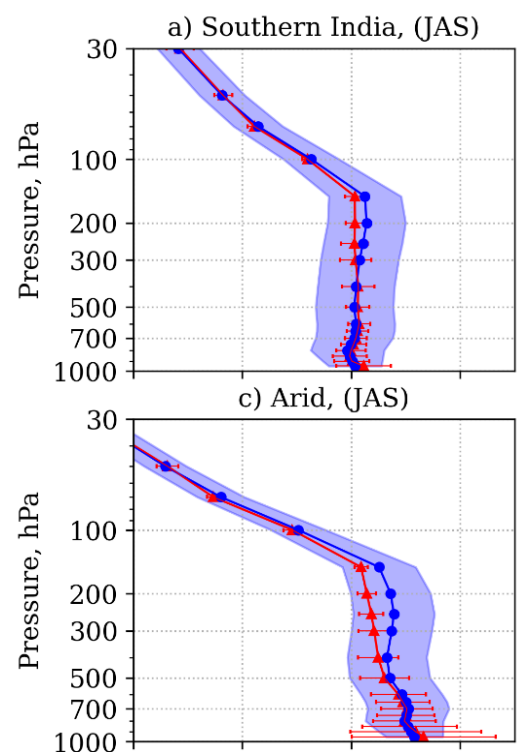

e) Northeast India, (JAS)

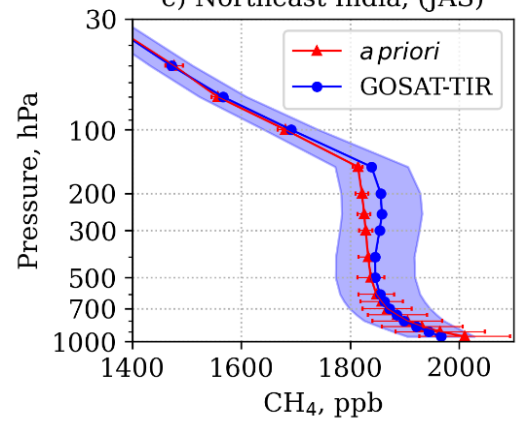

b) Southern India, (JAS)

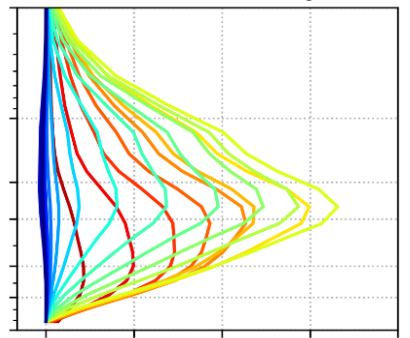

d) Arid, (JAS)

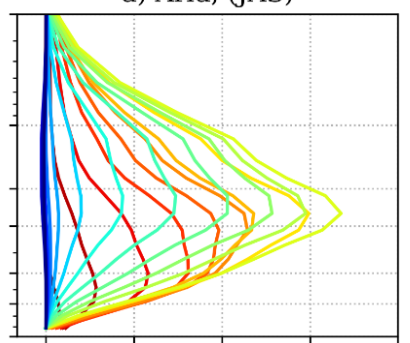

f) Northeast India, (JAS)

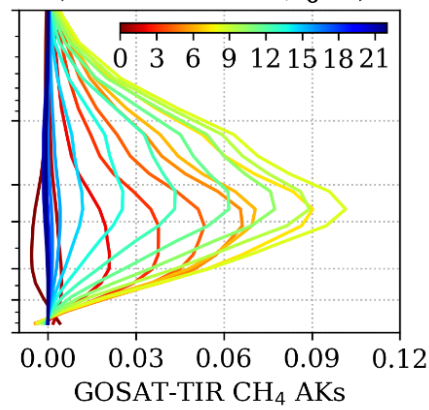

Figure 3. Seasonal mean (July-September 2011) over regions of Southern India (upper panel), Arid India (middle panel), and Northeast India (bottom panel). The left columns show the GOSAT-TIR CH4 a priori with 1- $\sigma$ STD uncertainty (red line with error bars) and GOSAT-TIR $\mathrm{CH}_{4}$ profile with the retrieval error (blue line with shaded area); the right columns depict the averaging kernels of GOSAT-TIR CH4 retrievals averaged over time. There are 22 lines for GOSAT-TIR retrievals, corresponding to the retrieval layers used in each of them. 
Through analysis of the AK profiles of the GOSAT-TIR V1 $\mathrm{CH}_{4}$ products, Zou et al. [AMT, 2016] show the sensitivity of GOSAT-TIR measurements gradually increases from the surface up and reaches a maximum at the levels of 300-600 hPa in the high latitudes and 200-600 hPa in the tropics. While below $800 \mathrm{hPa}$ the sensitivity is small reflecting the major limitation of TIR in measuring the change of $\mathrm{CH}_{4}$ in the lower troposphere. Figure 3 shows typical GOSAT-TIR $\mathrm{CH}_{4}$ profile with retrieval errors and a priori profile (left panels) and its corresponding AK profiles (right panels) for the Southern, Arid, and Northeast regions during the monsoon season. At the pressure levels of 500-150 hP where GOSAT-TIR measurements have sensitivity judging from their AK profiles, there are some differences between the retrieved and a priori $\mathrm{CH} 4$ profiles and they are beyond the retrieval errors, which means they should be significant differences.

\section{3 $\mathrm{CH}_{4}$ over India observed by GOSAT-TIR and simulated by MIROC4-ACTM}

In this section we analyzed $\mathrm{CH}_{4}$ distributions from GOSAT-TIR and MIROC4-ACTM at the levels of the constant pressure of 800,500 , and $200 \mathrm{hPa}$, which represents the top of the boundary layer, the free troposphere, and the upper troposphere parts of the atmosphere, respectively. Datasets were resampled on the grid with a resolution of $3.0 \times 3.0$ and interpolated along the vertical coordinate. $\mathrm{CH}_{4}$ concentrations were average in time for three periods: pre-monsoon April-June (AMJ), monsoon July-

215 September (JAS), and post-monsoon October-December (OND). The winter season (JFM), as no strong difference found in comparison with AMJ.

Due to a lack of GOSAT-TIR $\mathrm{CH}_{4}$ data in cloudy scenes and the influence of the complex orography of the studied area, the number of points used for averaging in each grid cell varies with height over land (Fig. 4d1-d3). This is especially noticeable for the northern regions of India, since a significant part of Tibet and the Himalayas are above the level of $800 \mathrm{hPa}$ (Fig. 4d1). Northern India also has large sources of $\mathrm{CH}_{4}$ with different types of emission. These two factors cause large standard deviations (STD) in $\mathrm{CH}_{4}$ (Fig. 4e1-43). For South India and the marine regions, the STD values are much lower compared to those over the land.

In the middle and upper troposphere, the perturbations from the heterogeneity of the emissions are smoothed out, the density of observation points increases, therefore, the averaging errors decrease. At a height of $200 \mathrm{hPa}$, the average STD for GOSAT-TIR is approximately $25 \mathrm{ppb}$.

The density of observation points decreases with the onset of the monsoon season (Fig. 5d1-d3), however, it remains sufficient to detect significant changes in $\mathrm{CH}_{4}$ concentrations even considering the relatively large STD values there. A significant increase in concentration values is noticeable primarily in the middle and upper parts of the atmosphere (Fig. 5a1a3), which is due to the repeatedly confirmed effect of convective transport from surface sources upward. After reaching a level near the tropopause, the increased concentrations are distributed by three jets: the lateral (the cross-equatorial circulation) and transverse (flows between the arid regions of north Africa and the Near East and south Asia) monsoons, and the Walker Circulation is extended across the Pacific Ocean [Webster et al., 1998]. The $\mathrm{CH}_{4}$ concentration in the eastern jets is higher, since it is formed over more northern areas with larger emission. The influence of the third component (the cross-equatorial circulation) is more noticeable in the post-monsoon period (Fig. S2). 
https://doi.org/10.5194/amt-2020-101

Preprint. Discussion started: 13 July 2020

(C) Author(s) 2020. CC BY 4.0 License.
Atmospheric

Measurement

Techniques

Discussions

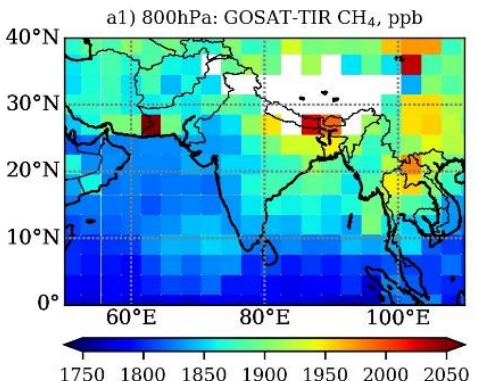

$1750180018501900 \quad 195020002050$
b1) $800 \mathrm{hPa}$ : GOSAT-TIR a priori $\mathrm{CH}_{4}, \mathrm{ppb}$

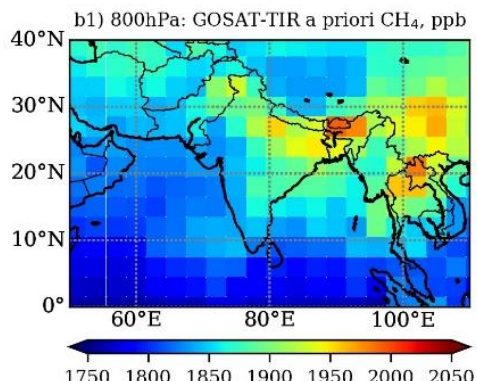

$\begin{array}{lllllll}1750 & 1800 & 1850 & 1900 & 1950 & 2000 & 2050\end{array}$ $\left.40^{\circ} \mathrm{c} 1\right)$

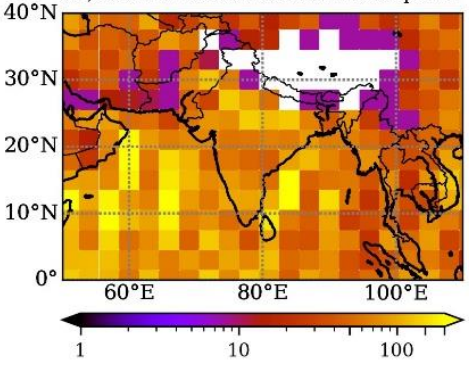

d1) $800 \mathrm{hPa}$ : GOSAT-TIR $\mathrm{CH}_{4}$ std, ppb

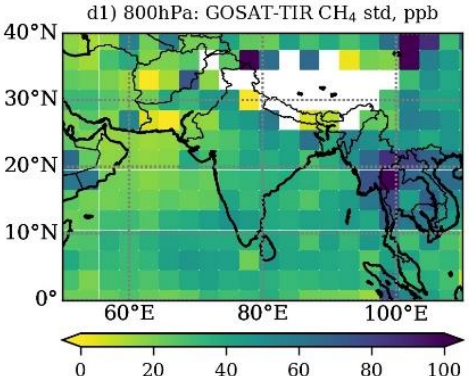

a2) 500hPa: GOSAT-TIR $\mathrm{CH}_{4}$, ppb

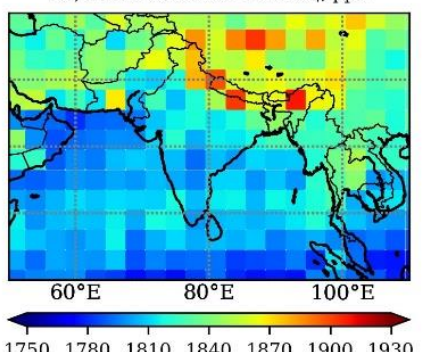

$1750 \quad 1780 \quad 1810 \quad 1840 \quad 1870 \quad 1900 \quad 1930$ b2) $500 \mathrm{hPa}$ : GOSAT-TIR a priori $\mathrm{CH}_{4}$, ppb

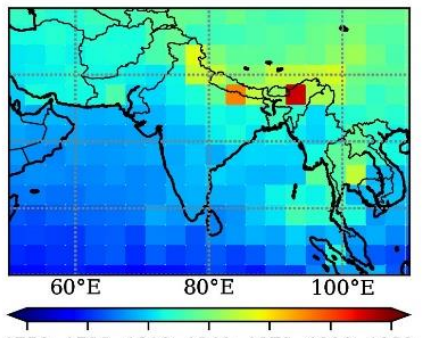

$\begin{array}{lllllll}1750 & 1780 & 1810 & 1840 & 1870 & 1900 & 1930\end{array}$ c2) $500 \mathrm{hPa}$ : Number of observation points

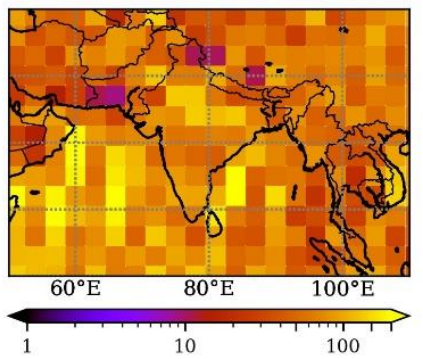

d2) $500 \mathrm{hPa}$ : GOSAT-TIR $\mathrm{CH}_{4}$ std, ppb

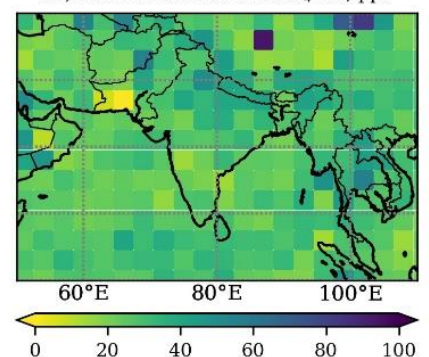

a3) 200hPa: GOSAT-TIR $\mathrm{CH}_{4}$, ppb
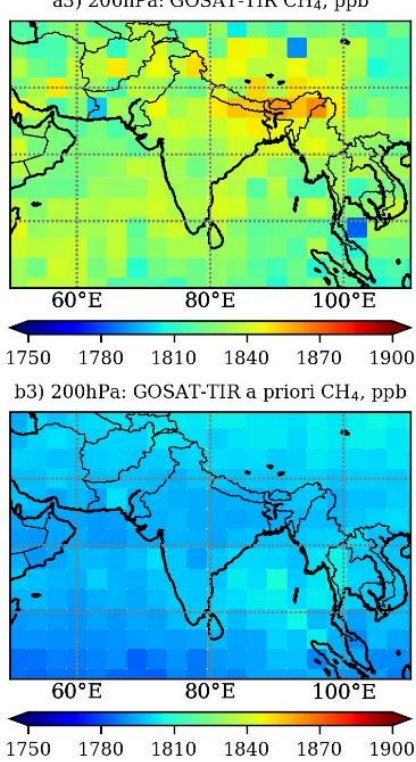

c3) $200 \mathrm{hPa}$ : Number of observation points

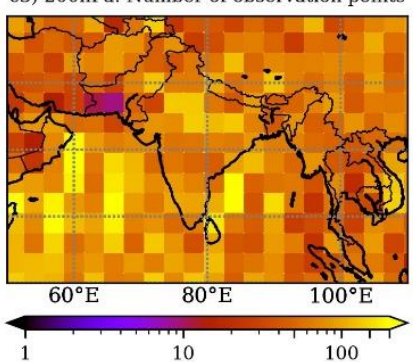

d3) 200hPa: GOSAT-TIR $\mathrm{CH}_{4}$ std, ppb

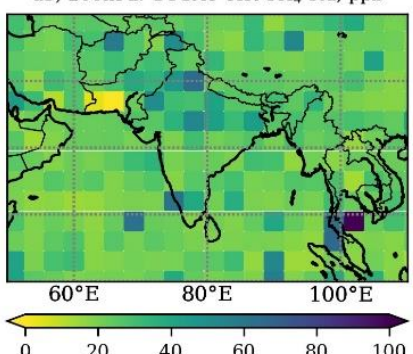

Figure 4: Latitude-longitude distributions of $\mathrm{CH}_{4}$ at the levels of 800,500 , and $200 \mathrm{hPa}$ (the left, middle, and right panels respectively) observed by GOSAT-TIR for the season AMJ 2011. The first upper panels (a1-a3) show GOSAT-TIR $\mathrm{CH}_{4}$, the second upper panels (b1-b3) show GOSAT-TIR a priori $\mathrm{CH}_{4}$, the third upper panels (c1-c3) the GOSAT-TIR observation points numbers, the fourth upper panels (d1-d3) show GOSAT-TIR $\mathrm{CH}_{4}$ standard deviation, respectively.

GOSAT-TIR $\mathrm{CH}_{4}$ retrievals are constrained to the a priori $\mathrm{CH}_{4}$ data (panels b1-b3 of Fig. 3-4) especially in lower pressure levels due to the relatively low signal-to-noise ratio of the TIR spectra at $\mathrm{CH}_{4}$ absorption bands [Saitoh et al., 2012, Zou et al., 2016]. Nevertheless, the GOSAT-TIR $\mathrm{CH}_{4}$ product shows vivid differences in $\mathrm{CH}_{4}$ from the a priori values even in the lower 
https://doi.org/10.5194/amt-2020-101

Preprint. Discussion started: 13 July 2020

(C) Author(s) 2020. CC BY 4.0 License.
Atmospheric

Measurement

Techniques

Discussions

part of the atmosphere, where sensitivity is weak (panels c1-c3 of Fig. 3-4). This implies an additional signal of $\mathrm{CH}_{4}$ concentration could be captured by the GOSAT-TIR measurements.

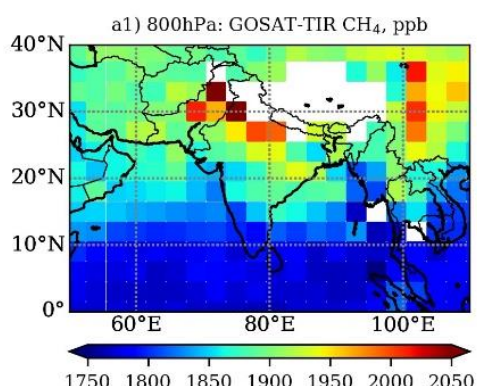

$\begin{array}{lllllll}1750 & 1800 & 1850 & 1900 & 1950 & 2000 & 2050\end{array}$ $40^{\circ} \mathrm{b} 1$ ) $800 \mathrm{hPa}$ : GOSAT-TIR a priori $\mathrm{CH}_{4}, \mathrm{ppb}$

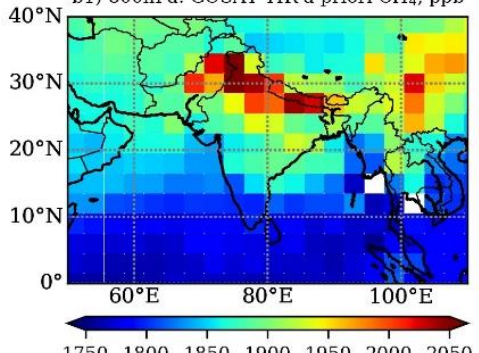

$17501800 \quad 18501900195020002050$ $40^{\circ} \mathrm{c} 1$ ) $800 \mathrm{hPa}$ : Number of observation points
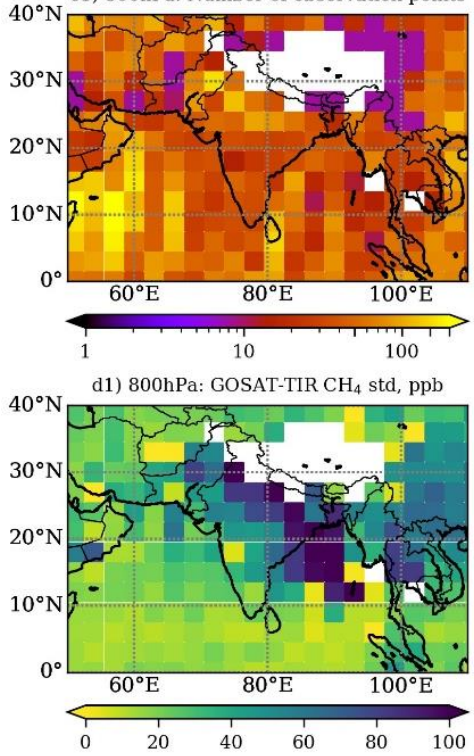

a2) 500hPa: GOSAT-TIR $\mathrm{CH}_{4}$, ppb

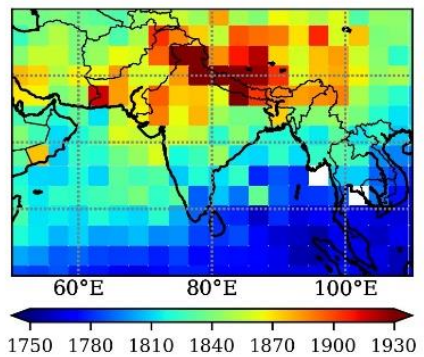

b2) 500hPa: GOSAT-TIR a priori $\mathrm{CH}_{4}$, ppb

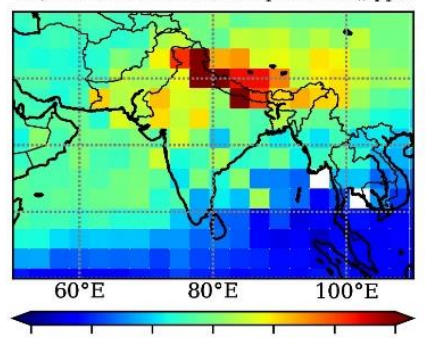

$\begin{array}{lllllll}1750 & 1780 & 1810 & 1840 & 1870 & 1900 & 1930\end{array}$

c2) $500 \mathrm{hPa}$ : Number of observation points

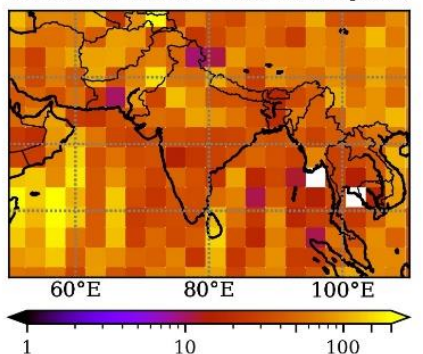

1

d2) 500hPa: GOSAT-TIR $\mathrm{CH}_{4}$ std, ppb

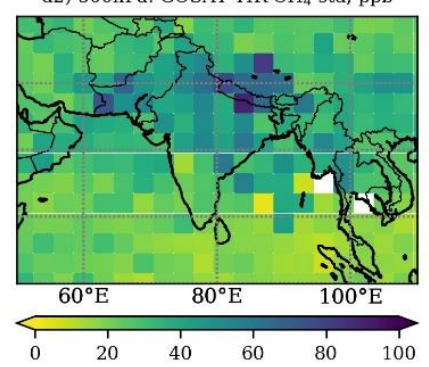

a3) 200hPa: GOSAT-TIR $\mathrm{CH}_{4}$, ppb

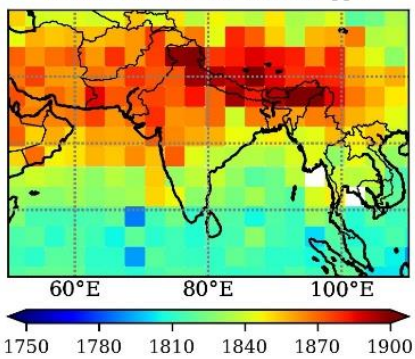

b3) 200hPa: GOSAT-TIR a priori $\mathrm{CH}_{4}$, ppb

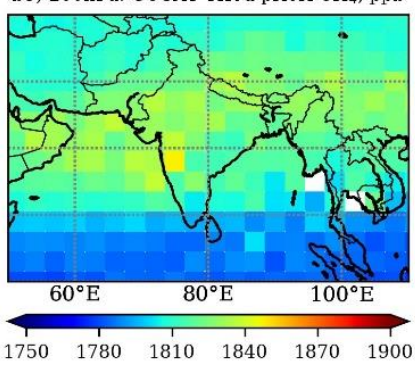

c3) $200 \mathrm{hPa}$ : Number of observation points

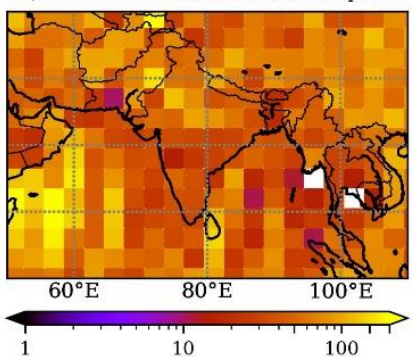

d3) 200hPa: GOSAT-TIR $\mathrm{CH}_{4}$ std, ppb

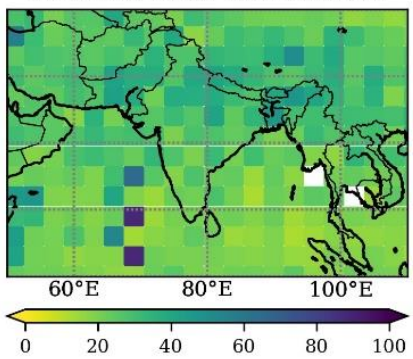

Figure 5: Same as Fig. 3, but for JAS 2011.

As explained in Section 2.2, MIROC4-ACTM simulations were performed with two flux combinations reflecting different 250 approaches for estimation of the wetland $\mathrm{CH}_{4}$ emission. In general, the WH scheme fluxes are about 5-10\% larger the Cao, 
https://doi.org/10.5194/amt-2020-101

Preprint. Discussion started: 13 July 2020

(c) Author(s) 2020. CC BY 4.0 License.

\section{Atmospheric \\ Measurement \\ Techniques \\ Discussions}

excepting the WIGP, EIGP, and NEI regions of India and Bangladesh where the maximum difference reaches 20-40\% (Fig. 6). Besides, there are small hot spots in Southeast Asia (e.g. Mekong River Delta).

Since in the pre- and post-monsoon seasons (AMJ and OND) the excess concentration due to additional emission is locked in the boundary layer (as seen from MOPITT CO) [Kar et al., 2010], we can detect only a slight increase in concentration at

the levels selected for the analysis. $\mathrm{CH}_{4}$ simulated using both emission schemes are consistent with the GOSAT-TIR retrieval with averaged mismatch within $\pm 2 \%$, the heterogeneity of which is apparently caused by transport regimes (see Fig. 7 for AMJ). By analogy to the $\mathrm{CH}_{4}$ distribution from GOSAT-TIR the increased scatter found in modeled $\mathrm{CH}_{4}$ over IGP, wherein the enhanced values extend up to the level of $200 \mathrm{hPa}$ (see supplement Fig. S4).

During the monsoon, the difference between emission scenarios becomes significant, as additional $\mathrm{CH}_{4} \mathrm{mass}_{1}$ is carried to 260 the middle and upper atmosphere (Fig. 8). The larger mismatch in comparison with GOSAT-TIR (Fig. 8b1-b3) emphasizes the redundancy of $\mathrm{CH} 4$ emission of the $\mathrm{WH}$ scheme.
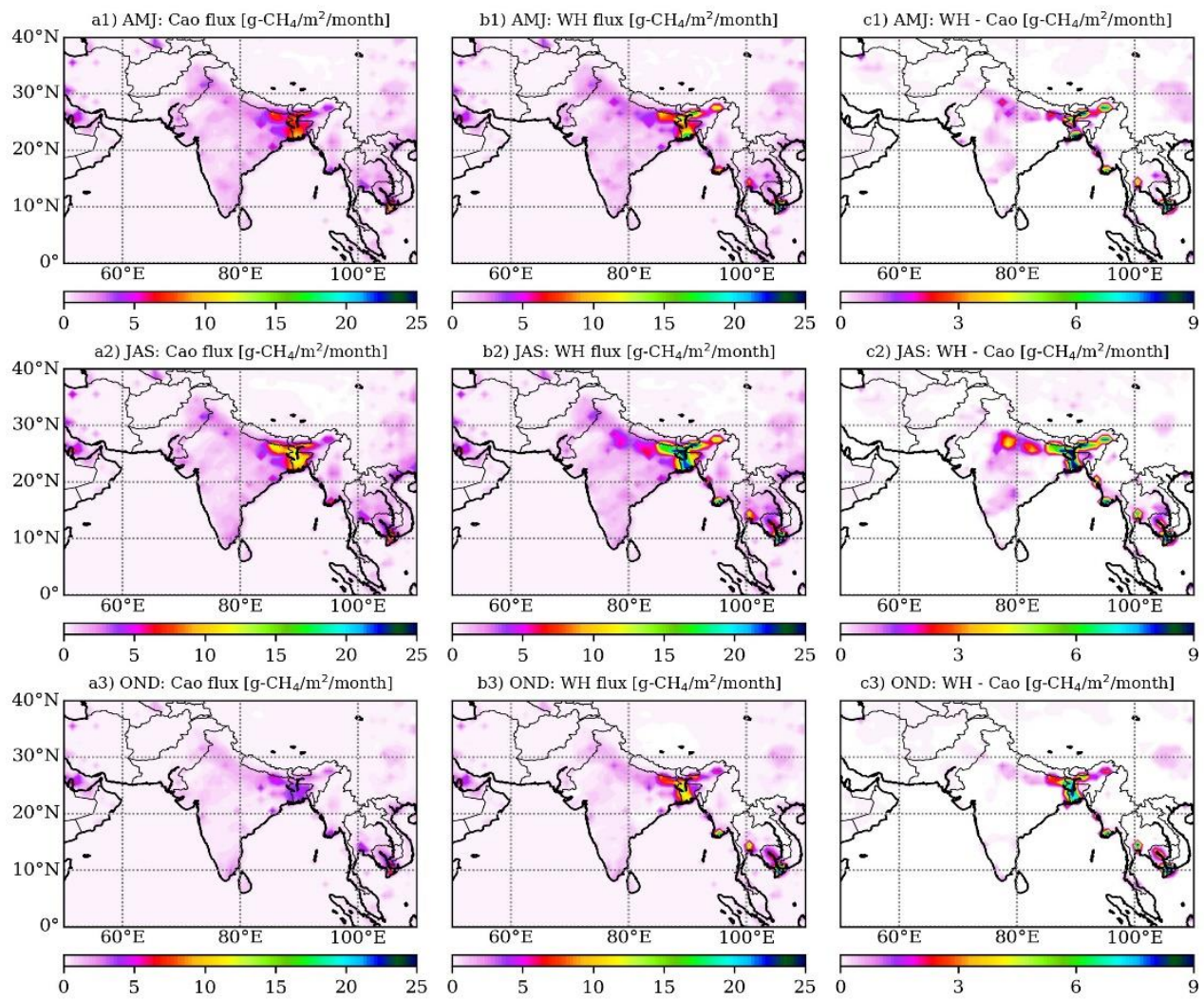

Figure 6: The surface $\mathrm{CH}_{4}$ fluxes (g-CH4 $/ \mathrm{m}^{2} / \mathrm{month}$ ) used for MIROC4-ACTM simulation: a1a3) from Cao scheme, b1-b3) from WH scheme, and c1-c3) difference between schemes. Panels a1-c1, a2-c2, and a3-c3 are for AMJ, JAS, and OND respectively. 
https://doi.org/10.5194/amt-2020-101

Preprint. Discussion started: 13 July 2020

(c) Author(s) 2020. CC BY 4.0 License.
Atmospheric

Measurement

Techniques

Discussions
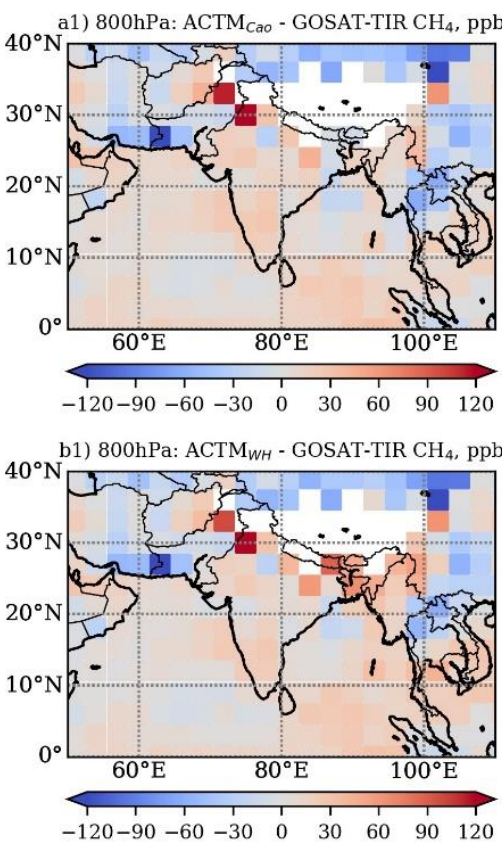
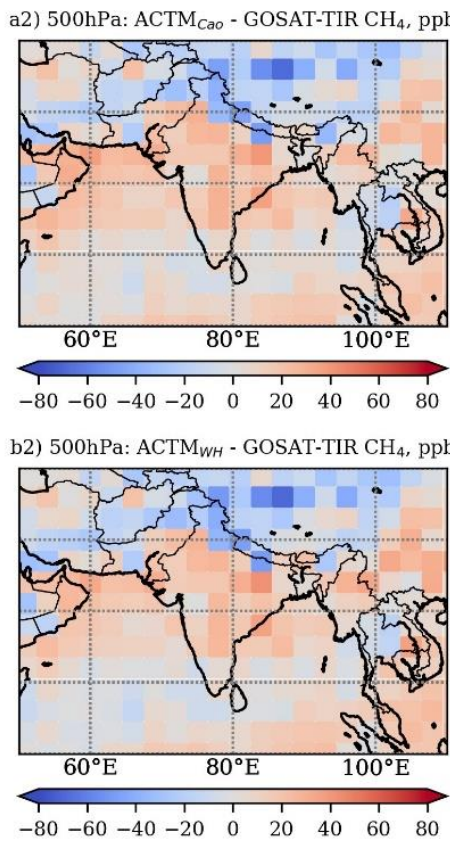

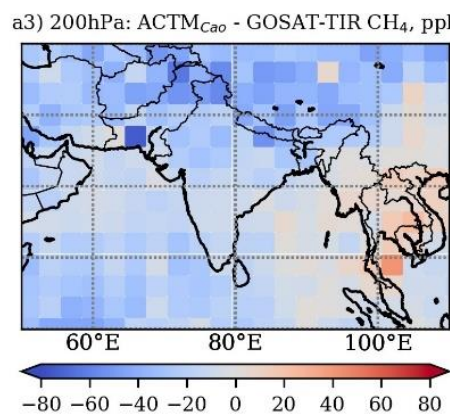

b3) 200hPa: ACTM ${ }_{W H}$ - GOSAT-TIR $\mathrm{CH}_{4}$, ppb

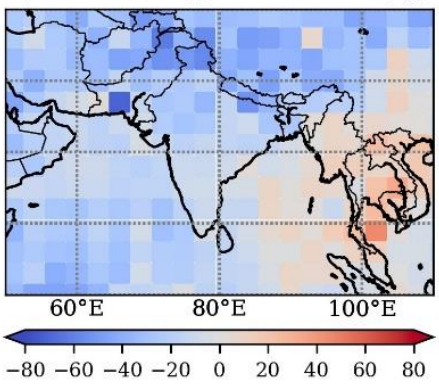

Figure 7: Latitude-longitude distributions of $\mathrm{CH}_{4}$ simulated by MIROC4-ACTM at the levels of 800, 500, and $200 \mathrm{hPa}$ (the left, middle, and right panels respectively) for AMJ 2011. The first (a1-a3) and second (b1-b3) upper panels show the difference in $\mathrm{CH}_{4}$ between GOSAT-TIR and ACTM ${ }_{C a}$ and ACTM $_{w H}$. The averaging kernel was not implemented.
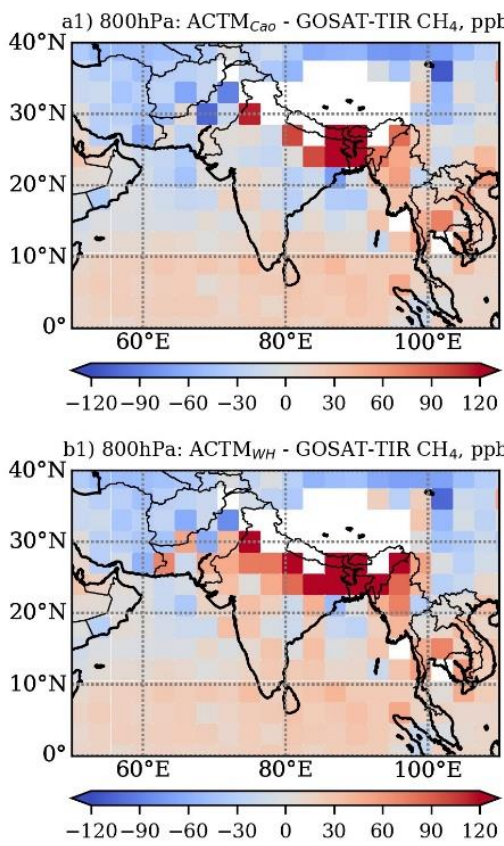

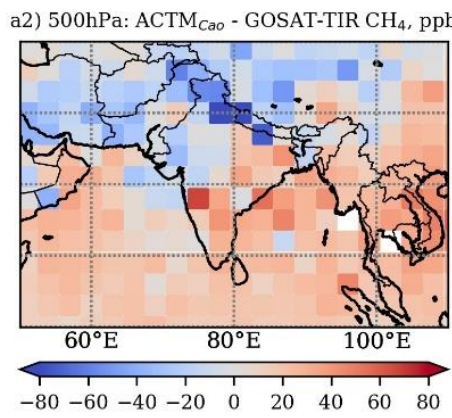

b2) 500hPa: ACTM $\mathrm{WH}_{W H}$ - GOSAT-TIR $\mathrm{CH}_{4}$, ppb

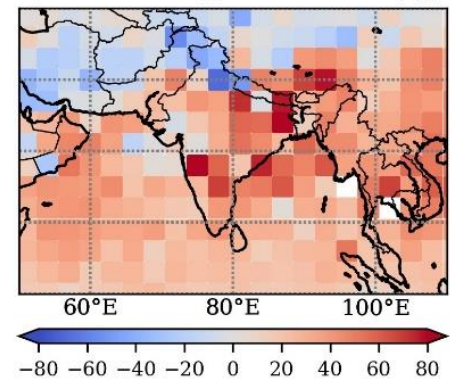

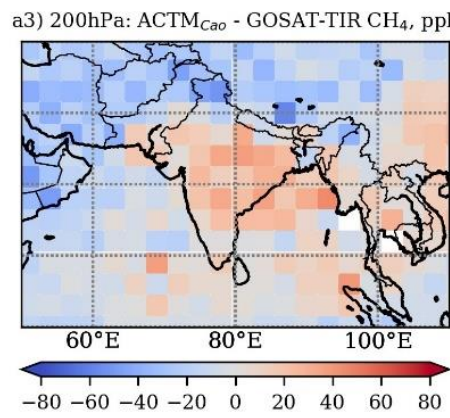

b3) $200 \mathrm{hPa}: \mathrm{ACTM}_{W H}$ - GOSAT-TIR $\mathrm{CH}_{4}$, ppb

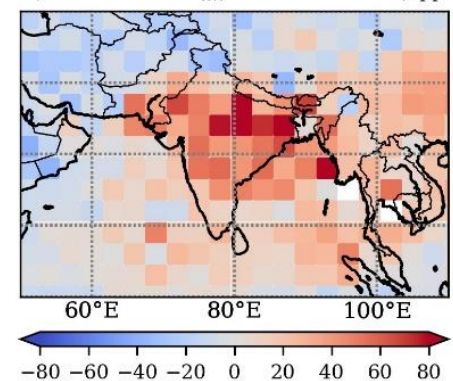

Figure 8: Same as Fig. 6, but for JAS 2011. 
https://doi.org/10.5194/amt-2020-101

Preprint. Discussion started: 13 July 2020

(c) Author(s) 2020. CC BY 4.0 License.
Atmospheric

Measurement

Techniques

Discussions

\section{4 $\mathrm{CH}_{4}$ vertical profiles}

This section aiming to investigate the $\mathrm{CH}_{4}$ tropospheric profile time and space variations above the Indian regions and to attribute the altitude $\mathrm{CH}_{4}$ variability to the regional emission strength and different synoptic and global scale depending on the season. Figure 9 depicts seasonal mean $\mathrm{CH}_{4}$ vertical profiles observed by GOSAT-TIR and simulated by the model for premonsoon (April-June) and monsoon (July-September) of 2011. The variation of GOSAT-TIR sensitivity are taking into account by the implementation of the averaging kernel the modelled data sets ( $\mathrm{ACTM}^{\mathrm{AK}}{ }_{C a o}$ and $\left.\mathrm{ACTM}^{\mathrm{AK}}{ }_{W H}\right)$.
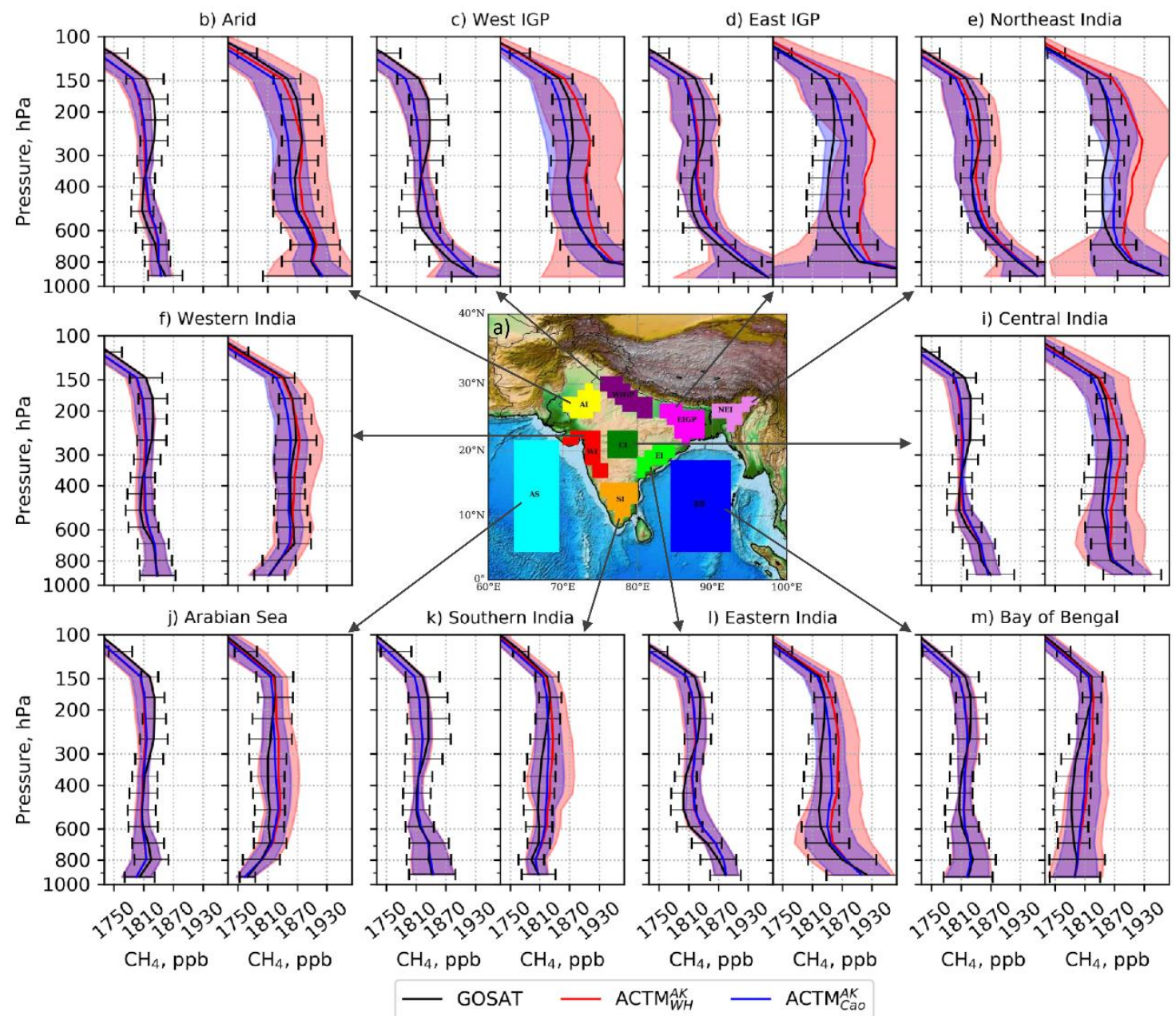

Figure 9: Seasonal mean $\mathrm{CH}_{4}$ vertical profiles for pre-monsoon (April-June) and monsoon (July-September) of 2011 are shown in the left and right part of each panels (b-m) for the different regions as depicted in the central map (a). Black line with error bars shows the GOSAT-TIR data with 1- $\sigma$ STD uncertainty. Blue and red lines with shaded areas correspond to the ACTM ${ }^{\mathrm{AK}}{ }_{C a o}$ and $\operatorname{ACTM}^{\mathrm{AK}}{ }_{W H}$ data with 1- $\sigma$ STD uncertainty, respectively. 
https://doi.org/10.5194/amt-2020-101

Preprint. Discussion started: 13 July 2020

(c) Author(s) 2020. CC BY 4.0 License.

\section{Atmospheric \\ Measurement \\ Techniques \\ Discussions}

By using the a priori and retrieved $\mathrm{CH}_{4}$ profiles with retrieval error and AK profile (Fig. 3), we found that differences between a priori and retrieved $\mathrm{CH}_{4}$ profiles are larger than its retrieval error, so the differences are valid to be discussed. The variabilities shown in Figure 9 are larger than GOSAT-TIR retrieval errors, so GOSAT-TIR and model show good agreements within both errors (natural variabilities and retrieval random errors).

The vertical $\mathrm{CH}_{4}$ profiles have a characteristic curved shape with double peak. The first peak near the surface is associated with emissions from local sources, the second one at the level of $150-200 \mathrm{hPa}$ is caused by the vertical updraft [Belikov et al., 2013, Saito et al., 2013]. Reflecting the increase of $\mathrm{CH}_{4}$ surface fluxes intensity (Fig. 6), the vertical gradient between the nearsurface and upper troposphere levels increases in the direction from South-West (marine regions (Fig. 9a,c) have slightly lower concentrations in the boundary layer since the sea is a weak source) to the North-Eastern (where EIGP, WIGP, and Northeast Indian stand out in significant sources due to various natural and anthropogenic sources (Fig. 9h,i,j)).
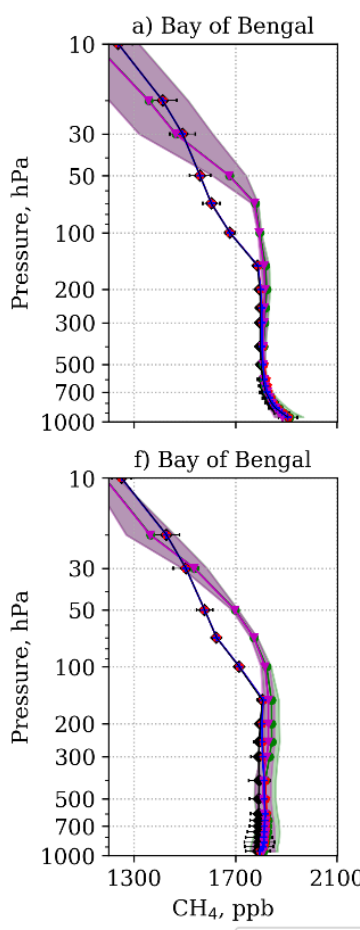

$\rightarrow$ GOSAT a priori b) Arid

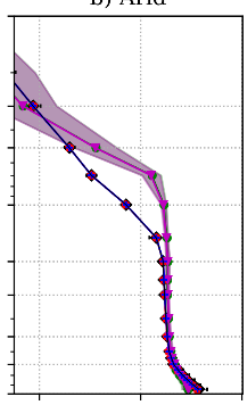

g) Arid

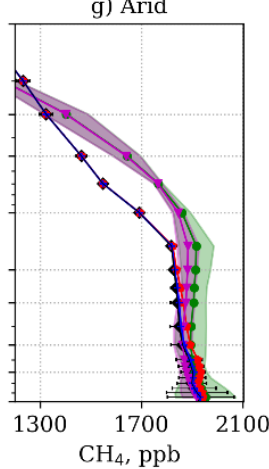

c) East IGP

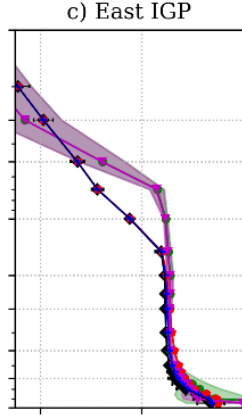

h) East IGP

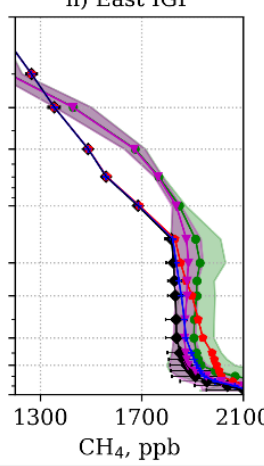

d) Northeast India
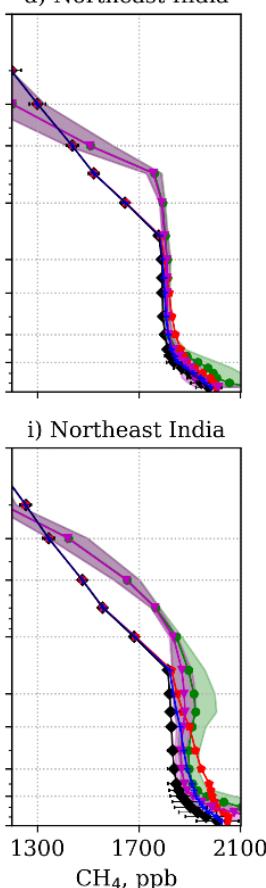

e) Western India
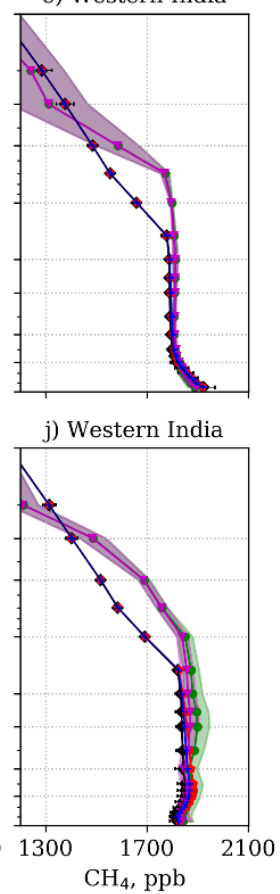

Figure 10: Seasonal mean $\mathrm{CH}_{4}$ vertical profiles (a-e) for winter (January-March) and (f-j) monsoon (July-September) periods of 2011 are shown for the selected regions. Black line shows the GOSAT-TIR a priori data. Green and magenta lines with shaded areas correspond to the $\operatorname{ACTM}_{W H}$ and ACTM $_{C a o}$ data with 1- $\sigma$ STD uncertainty, respectively. Red and blue lines represent the $\mathrm{CH}_{4}$ from $\mathrm{ACTM}^{A K}{ }_{W H}$ and $\mathrm{ACTM}^{A K}$ Cao smoothed with the averaging kernel implementation.

Monsoons cause a powerful perturbation of concentration along the entire vertical profile up to the level of the tropopause. Two southern regions (the Arabian Sea and Southern India; Fig. 9a,h) are located near the entry point of Somali Jet - 
atmospheric masses with a low $\mathrm{CH}_{4}$ coming from the Indian Ocean [Findlater, 1969]. These regions do not have significant sources of $\mathrm{CH}_{4}$, and therefore, concentration in the vertical profiles increase with height due to transport from other regions. The third southern region (Bay of Bengal; Fig. 9c) has similar properties, but at the same time, it is under the influence of transport from neighboring regions (i.e. East India, EIGP), as evidenced by a large spread near the surface.

The use of AK is taking into account the relatively low vertical resolution of satellite measurements and the change in the sensitivity of the retrieval by smoothing along the a priori profile and reduces the spread at the levels where the sensitivity of satellite sensors is weak. Convolution of modelled profiles with GOSAT-TIR $\mathrm{CH}_{4}$ averaging kernels (Eq. 1) smooths the model profiles to fit the GOSAT-TIR vertical resolution and reduce their mismatch. Fig. 10 shows GOSAT-TIR AK has significant smoothing, approaching the MIROC4-ACTM model profiles to a priori so much that the difference between the calculations for the Cao and WH emission scenarios becomes barely distinguishable. This is especially vivid above the level of $150 \mathrm{hPa}$, where the sensitivity of GOSAT-TIR there drops sharply and the satellite retrievals and the AK convolved model profiles strongly follow the a priori profiles.

315 The choice of an a priori profile (usually provided by model calculations) is an important point in retrieval problems. The TransCom-CH4 experiment [Patra et al., 2011] showed a significant scatter between the participated models, including the NIES model later selected for calculating GOSAT-TIR a priori profile. In our study, a significant difference in the methane profile gradient, its seasonal variability (winter and summer) between a priori and the MIROC4-ACTM model was revealed in UTLS zone (levels of 150-20 hPa). Apparently, the difference in modelling the tropopause region and the tracer transport into the lower stratosphere is a key factor. Here should be noted that MIROC4-ACTM uses a more modern reanalysis to calculate the meteorological parameter, and the vertical resolution (67 sigma-pressure levels) is quite higher than that of the NIES (47 sigma levels). Even more important, the stratospheric part of the NIES model was adjusted to observed age of air for $\mathrm{CO}_{2}$ and long-term satellite observations from $\mathrm{HALOE}$ for $\mathrm{CH}_{4}$ [Saeki et al. 2013]. This emphasizes the uncertainty in modelling transport processes near the tropopause derived by different methods.

From the moment GOSAT was launched, the calculation of a prior profiles is carried out according to the same scheme. This is important for the long-term consistency of the GOSAT-TIR $\mathrm{CH}_{4}$ product but does not take into account the significant improvements (for example, updated $\mathrm{OH}$ fields, reanalysis, convective parameterization) implemented for MIROC4-ACTM. This emphasizes the need to use custom a priori profiles in retrieval, which requires greater transparency of technical information from satellite projects. This problem is less noticeable, but no less relevant for satellite $\mathrm{CH}_{4}$ receivers operating in the SWIR band aiming to obtain the total column $\mathrm{CH}_{4}$.

\section{5 $\mathrm{CH}_{4}$ time-altitude variation}

The monsoon anticyclone shows substantial intra-seasonal oscillations, which are connected to variable forcing from transient deep convection over the Indian subcontinent and the Bay of Bengal. This variability is typically associated with active/break cycles of the monsoon with timescales of $\sim 10-20$ days. Significant correlations exist between outgoing longwave radiation (OLR; Fig. 2a2-d2) and circulation within the monsoon region, such that the entire balanced anticyclone varies in 
concert with convective heating: enhanced convection leads to warmer tropospheric temperatures, stronger anticyclonic circulation, and colder lower stratospheric (and tropopause) temperatures [Randel and Park, 2006]. This causes a significant heterogeneity of the flux transported upward and $\mathrm{CH}_{4}$ concentration in the upper layers during ASMA (Fig. 11).

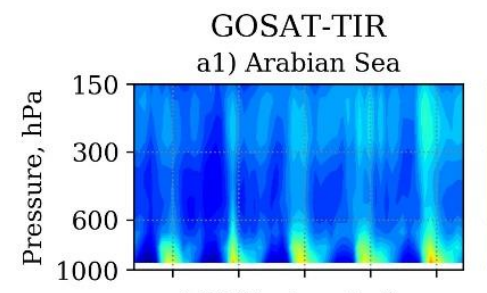

GOSAT a priori

a2) Arabian Sea

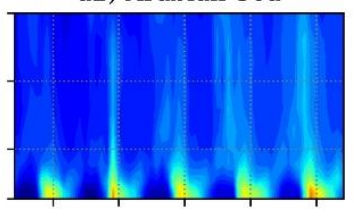

b2) Western India

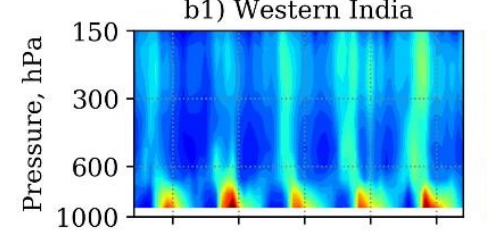

c1) Eastern India

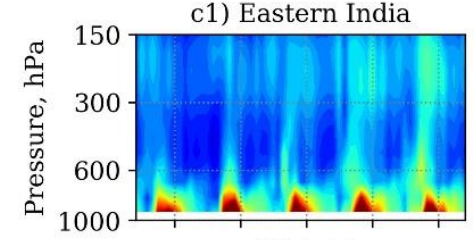

d1) Arid

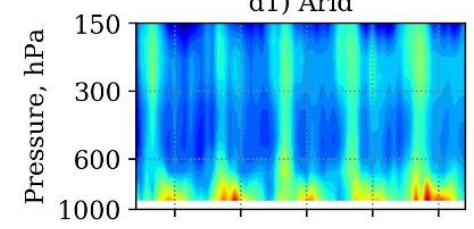

e1) Eeast IGP

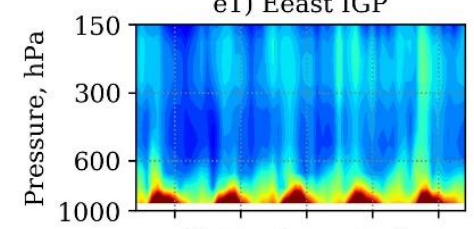

f1) Northeast India

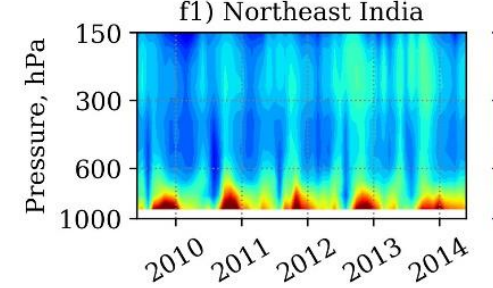

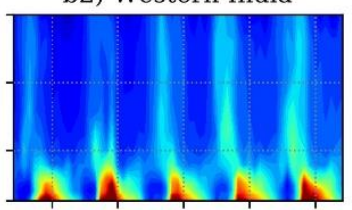

c2) Eastern India

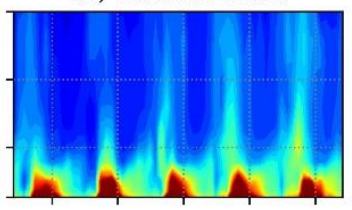

d2) Arid

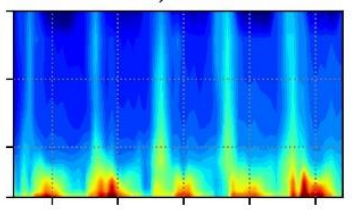

e2) Eeast IGP

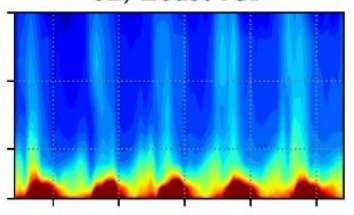

f2) Northeast India

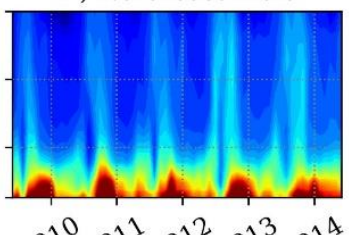

ACTM $_{\text {Cao }}$

a3) Arabian Sea

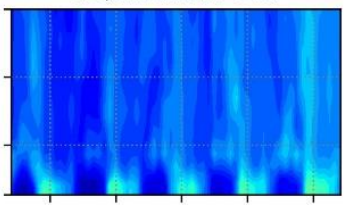

b3) Western India

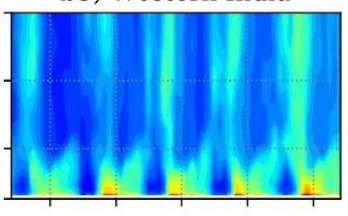

c3) Eastern India

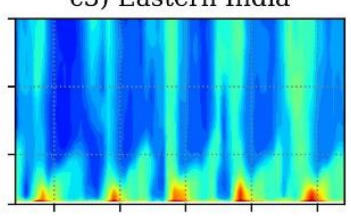

d3) Arid

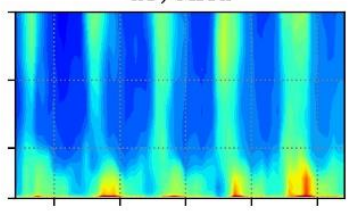

e3) Eeast IGP

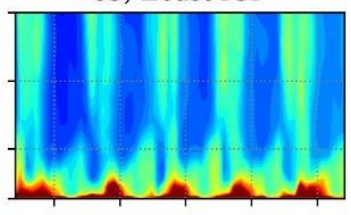

f3) Northeast India

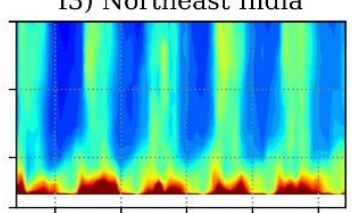

$201^{10} 20^{11} 20^{12} 20^{13} 20^{14}$

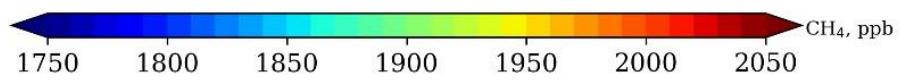

340 Figure 11: Time-altitude cross-section of $\mathrm{CH}_{4}$ form GOSAT-TIR retrieval, GOSAT-TIR a priori and ACTMCao (the left, middle, and right panels respectively) for considered regions. Note that the profiles are shown for the tropospheric altitudes as the GOSATTIR retrieval system is not sensitive to the stratospheric altitudes (See Fig. 9 and the associated text). 
The IGP region experiences intense agricultural activity, and use of traditional biofuels. In the winter months the IGP is often enveloped by thick fog and haze (Gautam et al., 2007). The prevailing winds at low altitudes (surface to $\sim 850 \mathrm{hPa}$ ) are northerly to northwesterly with low wind speeds $(<5 \mathrm{~m} / \mathrm{s})$ and the eastern parts of the IGP are impacted by a localized area of strong subsidence in winter [Dey and Di Girolamo, 2010]. These conditions tend to trap the pollution at low altitudes [Kar et al., 2010].

\subsection{Seasonal variation of $\mathrm{CH}_{4}$}

The Prophet time-series analysis and forecasting model [Taylor and Letham, 2018] was implemented to derive multi-year (2009-2014) seasonal variation of $\mathrm{CH}_{4}$ from GOSAT-TIR and MIROC4-ACTM. The model Prophet performs smoothing of time-series data based on a generalized additive model with three main components: trend, seasonality, and holidays. Compared to traditional exponential smoothing, Prophet can easily handle temporal patterns with multiple periods and has no requirements regarding the regularity of measurement spacing. The model has a robust performance in the presence of missing data and trend shifts and typically handles outliers well while working with time-series that have several seasons of historical data with strong seasonal patterns. The Prophet allows the use of all data points for the study period, thereby increasing accuracy and reducing sensitivity to random outliers [Belikov et al. 2019]. Though the GOSAT-TIR and MIROC4-ACTM mismatch in trend is almost negligible, the difference in the simulation of the amplitude and phase of the seasonal variation can be significant (Fig. 12).

Seasonal changes are controlled primarily by meteorological parameters, so the most noticeable effect is determined by the summer monsoon. During this season enhanced transport redistributes $\mathrm{CH}_{4}$ along all layers of the troposphere. The minimum $\mathrm{CH}_{4}$ seasonal variation is found in the lower troposphere ( $800 \mathrm{hPa}$ ), while the maximum occurs in the upper part (Fig. 12e-f).

The amplitude of seasonal changes is determined by the net amount of the sources; therefore, it increases from south to north from marine regions to the most densely populated areas. The figure 12 shows that a significant difference between the Cao and WH fluxes is evident in the three northern regions (WIGP, EIGP and NEI). During summer their differences can reach almost $50 \%$. This inequality determines the difference between seasonal variability not only for these regions, but also for the nearest neighbours. Especially noticeable for AI and WI, where intrinsic fluxes are much small.

With the onset of autumn, the deep convective transport is suppressed, therefore under the influence of the Hadley cell circulation the slow outflow of air masses is started in the opposite south-west direction. This moment is characterized by the peak of concentration at $800 \mathrm{hPa}$, which slowly moves from the northern regions (over EIGP in October) to the southern (over Arabian Sea in the late November).

India occupies a large region of South Asia, where a fewer observations limit the chance to reduce the uncertainty in the greenhouse gases (including methane) flux. Used in this work the Cao and WH flux combinations for the South Asia region for the period 2009-2014 account $65.7 \pm 2.1$ and $82.4 \pm 2.8 \mathrm{Tg} \mathrm{yr}^{-1}$ respectively. In order to identify which emission scenario is more realistic, we compared the monthly mean methane concentrations averaged over the region's surface area Fig. 13. For 
https://doi.org/10.5194/amt-2020-101

Atmospheric

Preprint. Discussion started: 13 July 2020

(c) Author(s) 2020. CC BY 4.0 License.

Measurement

Techniques

Discussions

375 all considered levels, $\mathrm{ACTM}_{W H}$ is superior to $\mathrm{ACTM}_{C a o}$. However, a comparison with GOSAT-TIR may lead to a slightly different results depending on the level selected for comparison.

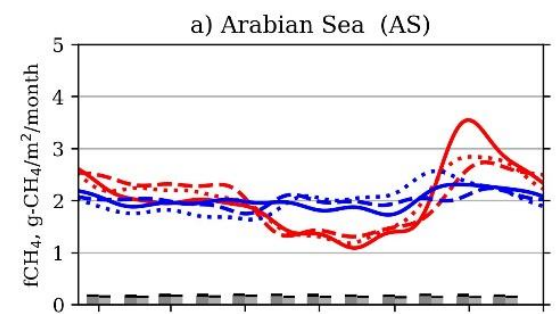

c) Southern India (SI)

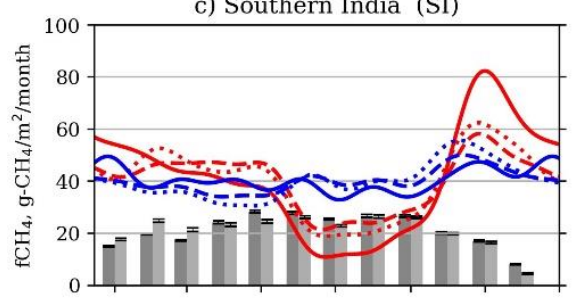

e) Central India (CI)

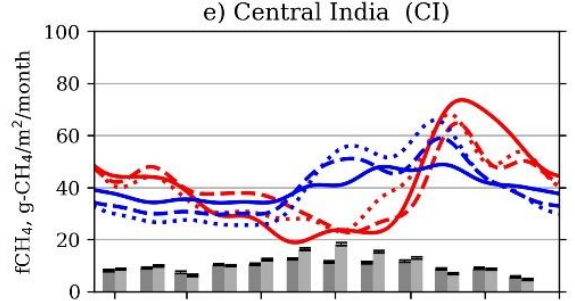

g) Arid (AI)

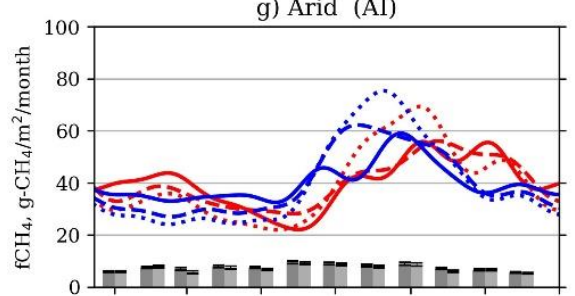

i) EIGP (EIGP)

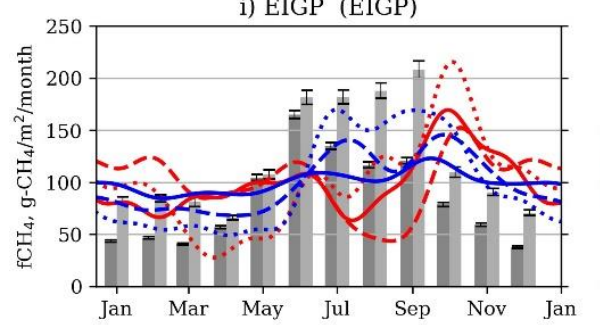

- GOSAT-TIR 800hPa - GOSAT-TIR 200hP

-- ACTM $_{\text {Саo }} 800 \mathrm{hPa} \quad$ - ACTM $_{\text {Сао }} 200 \mathrm{hPa}$ .... ACTM $_{W H} 800 \mathrm{hPa} \quad \ldots .$. ACTM $_{W H} 200 \mathrm{hPa}$ b) Bay of Bengal (BB)

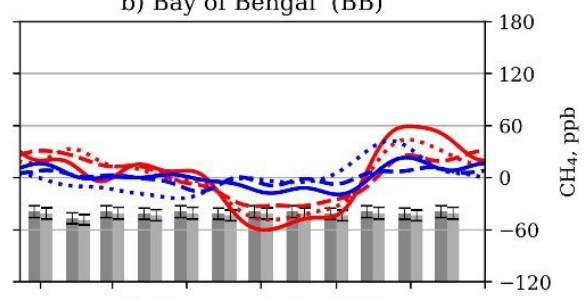

d) Western India (WI)

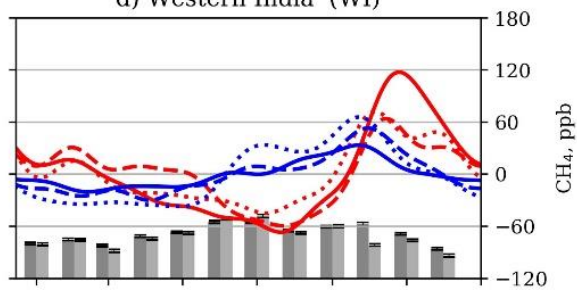

f) Eastern India (EI)

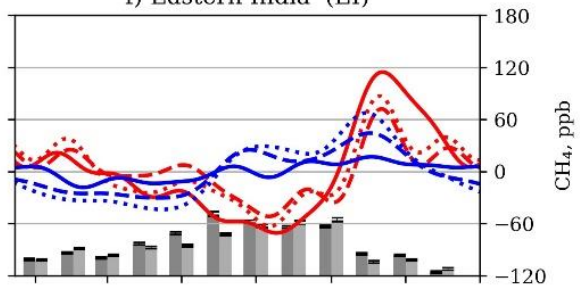

h) WIGP (WIGP)

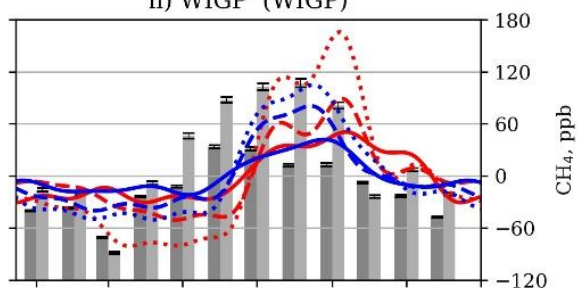

j) Northeast India (NEI)

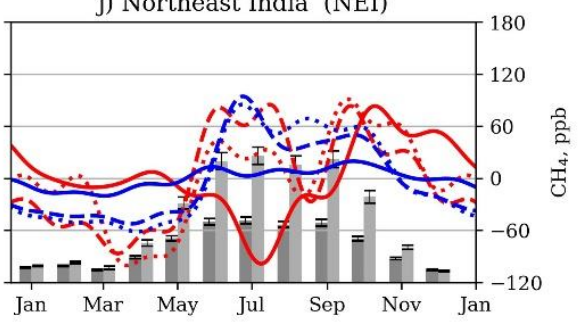

$\mathrm{fCH}_{4}(\mathrm{CaO}) \quad \mathrm{fCH}_{4}(\mathrm{WH})$

Figure 12: Seasonal variation of $\mathrm{CH}_{4}$ (right y-axis) derived for levels of 800 (red lines) and $200 \mathrm{hPa}$ (blue lines) over considered regions from GOSAT-TIR (solid line), ACTMCao (dashed line), and ACTMwH (dotted line), respectively. At the background bar plots represent $\mathrm{Cao}$ and $\mathrm{WH} \mathrm{CH}_{4}$ fluxes (left $\mathrm{y}$-axis). Please note the different scale of $\mathbf{y}$-axes (left) for fluxes. 
Again three levels $(800,500,200 \mathrm{hPa}$ ) were considered. At the top of the boundary layer (Fig. 13c) GOSAT-TIR shows significant inter-seasonal variability, which can be greatly influenced due to the large spread (large STD values) of individual samplings (Fig. 4-5 panels d1-d3)). Another important factor is the GOSAT-TIR retrieval a priori profile derived from NIES TM with the coarse vertical grid and simplified scheme for modeling of the boundary layer height, which shows strong diurnal and seasonal variations [Kavitha et al., 2018]. In UTLS significant seasonal fluctuations also occur (Fig. 13a).
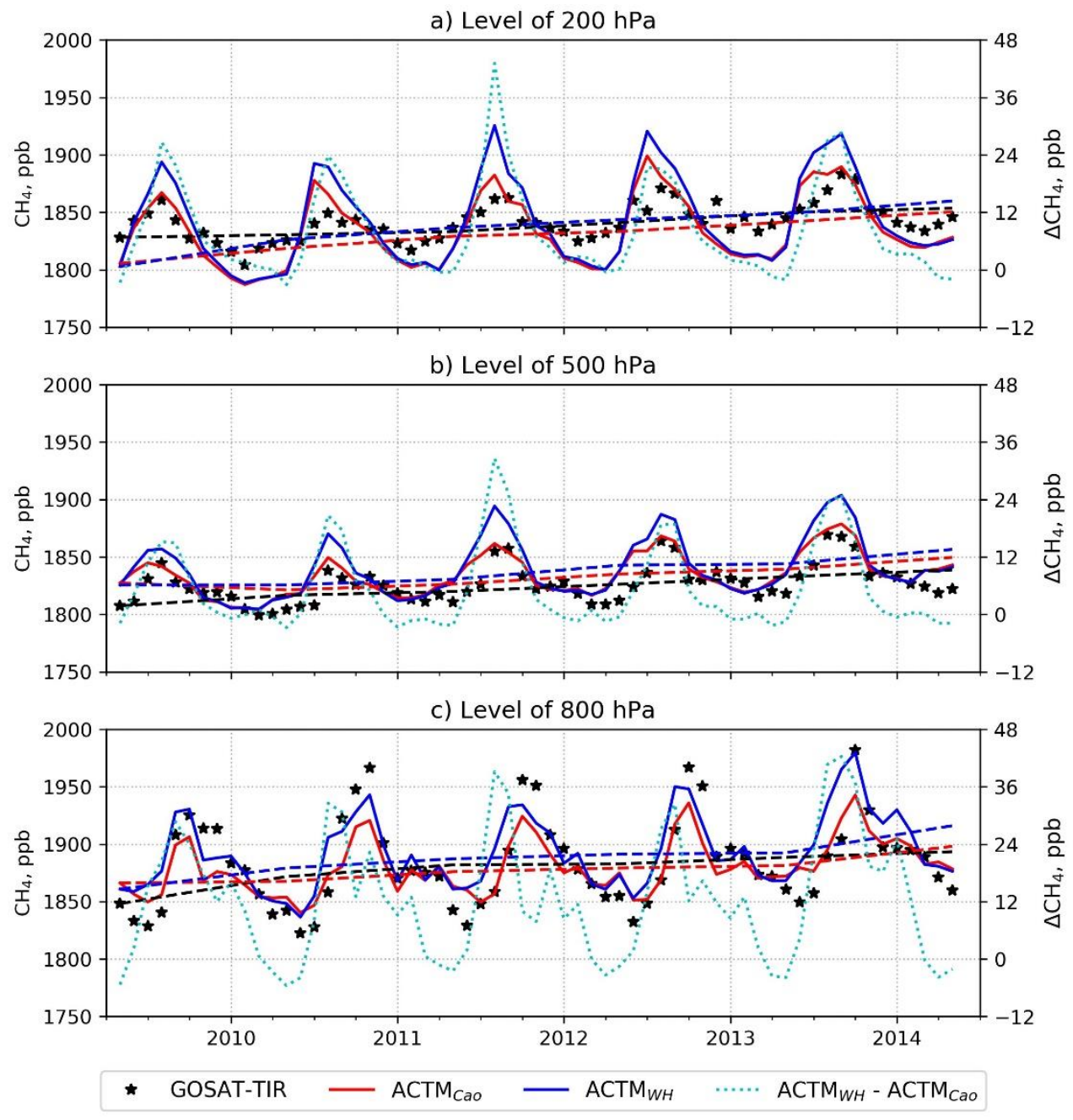

Figure 13: Time series of $\mathrm{CH}_{4}$ averaged over the area of South Asia for levels of a) 200, b) 500 and c) 800 hPa respectively. Symbols state the GOSAT-TIR observations, red and blue lines are for ACTMCao, and ACTMwH, respectively. Solid and dashed lines are for monthly and yearly averaged concentrations (left $y$-axis), dotted line shows the difference between the model simulations (right $y$-axis), respectively. The averaging kernel was not implemented. 
The strong summer peak in the MIROC4- $\mathrm{ACTM} \mathrm{CH}_{4}$ is associated with excessive vertical transport, which, apparently was not completely resolved upon the transition to the new (MIROC-4.0) meteorology. Moreover, it remains unclear what causes significant drops in concentration in the winter period. In the middle troposphere (Fig. 13b) a good consistency in phase is found and the $\mathrm{ACTM}_{C a o}$ to $\mathrm{ACTM}_{W H}$ concentration mismatch is strongly associated with the flux difference. Relying on this comparison results, we can suggest the Cao flux combination as more reliable emission estimation. This confirm the assessment made by Patra et al. [2016], indicating that the EDGAR inventory (version 4.2FT2010) overestimated the South Asia regional emission by $10-15 \mathrm{Tg} \mathrm{yr}^{-1}$. A significant part of the extra fluxes is concentrated in a few relatively small regions in the Northen India (fig. 6). However, our best estimate emission of $51.2 \pm 1.6 \mathrm{Tg} \mathrm{yr}^{-1}$ over the India is much greater than

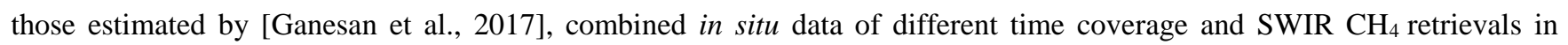
trajectory-based modelling framework.

\section{Conclusions}

Vertical profile observations of $\mathrm{CH}_{4}$ from GOSAT-TIR at 22 pressure layers and simulations by MIROC4-ACTM, sampled

at the location and time of the satellite overpass, were analyzed over India and surrounding oceanic regions for the period 2009-2014. The area of our analysis is subdivided in to several land and ocean regions. The main highlights of the present study are summarized below:

1. GOSAT-TIR observations provide data coverage and density suitable to study detailed horizontal features of $\mathrm{CH}_{4}$ at the top of the atmospheric boundary layer (excepting high mountain regions), free troposphere, and upper troposphere. While [Chandra et al., 2017] mainly used the model simulations to understand the vertical transport (after validating the model using GOSAT-SWIR measurements), using GOSAT-TIR measurements we show the seasonal evolution of transport and emissions on the $\mathrm{CH}_{4}$ at different layers of the troposphere using both the model and measurements.

2. The GOSAT-TIR product shows vivid differences in $\mathrm{CH}_{4}$ from the a priori values even in the lower part of the troposphere, where sensitivity of the TANSO-FTS sensor is relatively weak compared to the middle and upper troposphere. This implies an additional signal of $\mathrm{CH}_{4}$ concentration signal was captured by the TIR observations.

3. Distinct seasonal variations of $\mathrm{CH}_{4}$ have been observed at the different levels of the troposphere over northern and southern regions of India corresponding to the southwest monsoon (July-September) and early autumn (OctoberDecember) seasons. The major contrast between monsoon, and pre- and post-monsoon profiles of $\mathrm{CH}_{4}$ over Indian regions are noticed near the boundary layer levels. This is mainly caused by seasonal change in local emission strength. Unlike the work by [Guha et al., 2018], we found a strong difference between seasons in the middle and upper troposphere caused by variability in atmospheric circulation and vertical convection.

4. Even if no averaging kernel incorporated, the mean MIROC4-ACTM and GOSAT-TIR mismatches are within 50 $\mathrm{ppb}$, except for the level of $150 \mathrm{hPa}$ and upward, where the GOSAT-TIR sensitivity becomes very low. Convolution of the modeled profiles with retrieval a priori and averaging kernels reduce the mismatch to below uncertainty. 
However, the influence of the a priori profiles becomes too large with such smoothing. In comparison with AIRS satellite observation [Kavitha and Nair, 2019], finer vertical resolution of GOSAT-TIR allows capturing more detailed features in $\mathrm{CH}_{4}$ vertical profiles. Consequently, we obtained more prominent $\mathrm{CH}_{4}$ patterns related to different regions and seasons.

5. The significant difference in the methane profile gradient, its seasonal variability (winter and summer) between a priori (derived from the NIES TM simulations) and the MIROC4-ACTM model was revealed in UTLS zone (levels of 150-20 hpa). During monsoon season daily variation in a priori profiles is found in the middle troposphere. Thus, additional studies with use of custom a priori profiles in retrieval is of great importance.

6. Although we found the noticeable error in the model data in phase and amplitude at the end of summer-fall period, the performance of MIROC4-ACTM in $\mathrm{CH}_{4}$ transport in the troposphere and the lower stratosphere was improved due to the use of MIROC4.0 as the meteorological model. Furthermore, an additional analysis with aircraft observations is necessary to analyze the GOSAT-TIR and MIROC4-ACTM mismatch found above the level of $150 \mathrm{hPa}$. Our results suggest that the selection of a priori model for satellite data retrieval could play a significant role and should be addressed in the developments of future retrieval systems.

7. Among the two emission scenarios considered above, the Cao scheme seems to be more balanced than WH for individual regions and the whole South Asia during the monsoon season. In the other periods, no strong difference was found. Using the Cao and WH emission combinations, the annual mean emission for the South Asia region is estimated to $65.7 \pm 2.1 \mathrm{Tg} \mathrm{yr}^{-1}$ for the period 2009-2014.

Overall, the MIROC4-ACTM simulations of $\mathrm{CH}_{4}$ in the Indian regions compare favorably with the GOSAT-TIR samplings, in terms of seasonality and global variability. Inconsistencies seen in the GOSAT-TIR and MIROC4-ACTM comparisons could provide opportunities for further flux optimization with inverse modeling methods. More insight could be obtained after the extension of the released data period of the GOSAT-TIR $\mathrm{CH}_{4}$ product. 
Author contributions. Conceptualization, methodology: N.S. and P.P.; formal analysis, and original draft preparation: D.B.; GOSAT-TIR $\mathrm{CH}_{4}$ data primary processing: N.S.; MIROC4-ACTM flux optimization: N.C.; discussion, writing review and editing: all co-authors.

Competing interests. The authors declare no conflict of interest.

Code and data availability. GOSAT/TANSO-FTS TIR and a priori $\mathrm{CH}_{4}$ data and TIR CH4 averaging kernel data are

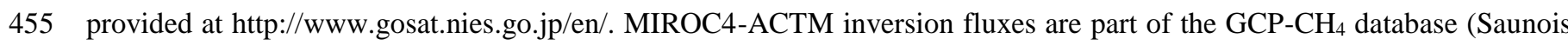
et al., ESSD, 2020) and are also downloadable from https://ebcrpa.jamstec.go.jp/ prabir/data/ch412r53/gcp2019/. Additional data requests regarding MIROC4-ACTM CH4 concentrations should be addressed to Dmitry Belikov (d.belikov@chibau.jp). All data processing codes are developed using Python and can be made available up to request to the corresponding author.

Acknowledgements. This research was supported by the Environment Research and Technology Development Fund (21802) of the Environmental Restoration and Conservation Agency of Japan. We also acknowledge the MODIS mission scientists and associated NASA personnel for the production of the data used in this research effort. Analyses and visualizations used in this paper were partly produced with the Giovanni online data system, developed and maintained by 465 the NASA GES DISC. 


\section{References}

Acker, J. G. and Leptoukh, G.: Online analysis enhances use of NASA earth science data, Eos, Transactions American Geophysical Union, 88, 14-17, 2007.

Akimoto, H.: Global air quality and pollution, Science, 302, 1716-1719, 2003.

Belikov, D., Maksyutov, S., Krol, M., Houweling, S., Fraser, A., Palmer, P., Rigby, M., Bian, H., Kawa, S., Agusti-Panareda, A., et al.: Off-line algorithm for calculation of vertical tracer transport in the troposphere due to deep convection, Atmospheric Chemistry and Physics, 13, 1093-1114, 2013.

Belikov, D., Arshinov, M., Belan, B., Davydov, D., Fofonov, A., Sasakawa, M., and Machida, T.: Analysis of the Diurnal, Weekly, and Seasonal Cycles and Annual Trends in Atmospheric CO2 and CH4 at Tower Network in Siberia from 2005 to 2016, Atmosphere, 10, $689,2019$.

Bergman, J. W., Fierli, F., Jensen, E. J., Honomichl, S., and Pan, L. L.: Boundary layer sources for the Asian anticyclone: Regional contributions to a vertical conduit, Journal of Geophysical Research: Atmospheres, 118, 2560-2575, 2013.

Buchwitz, M. d., Beek, R. d., Burrows, J., Bovensmann, H., Warneke, T., Notholt, J., Meirink, J., Goede, A., Bergamaschi, P., Körner, S., et al.: Atmospheric methane and carbon dioxide from SCIAMACHY satellite data: initial comparison with chemistry and transport models, Atmospheric Chemistry and Physics, 5, 941-962, 2005.

Butz, A., Hasekamp, O., Frankenberg, C., Vidot, J., and Aben, I.: CH4 retrievals from space-based solar backscatter measurements: Performance evaluation against simulated aerosol and cirrus loaded scenes, Journal of Geophysical Research: Atmospheres, 115, 2010.

485 Cao, M., Marshall, S., and Gregson, K.: Global carbon exchange and methane emissions from natural wetlands: Application of a process based model, Journal of Geophysical Research: Atmospheres, 101, 14399-14414, 1996.

Chandra, N., Hayashida, S., Saeki, T., and Patra, P. K.: What controls the seasonal cycle of columnar methane observed by GOS AT over different regions in India? Atmospheric Chemistry and Physics, 17, 12633-12643, 2017.

Chandra, N., Venkataramani, S., Lal, S., Patra, P., Ramonet, M., Lin, X., and Sharma, S.: Observational evidence of high methane emissions over a city in western India, Atmospheric environment, 202, 41-52, 2019.

Chandra, N., Patra, P. K., Bisht, J. S. H., Ito, J. S. H., Morimoto, S., Maenhout, G., Umezawa, T., Fujita, R., Takigawa, M., Watanabe, S., Aoki, S., Saitoh, N., and Saigusa, N.: Dominance of anthropogenic emissions on the global methane growth rate during 19882016, Scientific Reports, in review, 2020.

Crevoisier, C., Nobileau, D., Fiore, A. M., Armante, R., Chédin, A., and Scott, N.: Tropospheric methane in the tropics-first year from 495 IASI hyperspectral infrared observations, Atmospheric Chemistry and Physics, 9, 6337-6350, 2009.

Crevoisier, C., Nobileau, D., Armante, R., Crépeau, L., Machida, T., Sawa, Y., Matsueda, H., Schuck, T., Thonat, T., Pernin, J., et al.: The 2007-2011 evolution of tropical methane in the mid-troposphere as seen from space by MetOp-A/IASI, Atmospheric Chemistry and 350 Physics, 13, 4279-4289, 2013.

de Lange, A. and Landgraf, J.: Methane profiles from GOSAT thermal infrared spectra, Atmospheric Measurement Techniques, 11, 3815-3828, https://doi.org/10.5194/amt-11-3815-2018, https://www.atmos-meas-tech.net/11/3815/2018/, 2018.

Devasthale, A. and Fueglistaler, S.: A climatological perspective of deep convection penetrating the TTL during the Indian summer monsoon from the AVHRR and MODIS instruments, Atmospheric Chemistry and Physics, 10, 4573-4582, https://doi.org/10.5194/acp-10-4573355 2010, https://www.atmos-chem-phys.net/10/4573/2010/, 2010. 
Dey, S. and Di Girolamo, L.: A climatology of aerosol optical and microphysical properties over the Indian subcontinent from 9 years (2000-2008) of Multiangle Imaging Spectroradiometer (MISR) data, Journal of Geophysical Research: Atmospheres, $115,2010$.

Findlater, J.: A major low-level air current near the Indian Ocean during the northern summer, Quarterly Journal of the Royal Meteorological Society, 95, 362-380, 1969.

Fleitmann, D., Burns, S. J., Mangini, A., Mudelsee, M., Kramers, J., Villa, I., Neff, U., Al-Subbary, A. A., Buettner, A., Hippler, D., et al.: Holocene ITCZ and Indian monsoon dynamics recorded in stalagmites from Oman and Yemen (Socotra), Quaternary Science Reviews, 26, 170-188, 2007.

Frankenberg, C., Aben, I., Bergamaschi, P., Dlugokencky, E., Van Hees, R., Houweling, S., Van Der Meer, P., Snel, R., and Tol, P.: Global column-averaged methane mixing ratios from 2003 to 2009 as derived from SCIAMACHY: Trends and variability, Journal of Geophysical 365 Research: Atmospheres, 116, 2011.

Fu, R., Hu, Y., Wright, J. S., Jiang, J. H., Dickinson, R. E., Chen, M., Filipiak, M., Read, W. G., Waters, J. W., and Wu, D. L.: Short circuit of water vapor and polluted air to the global stratosphere by convective transport over the Tibetan Plateau, Proceedings of the National Academy of Sciences, 103, 5664-5669, 2006.

Ganesan, A. L., Rigby, M., Lunt, M. F., Parker, R. J., Boesch, H., Goulding, N., Umezawa, T., Zahn, A., Chatterjee, A., Prinn, R. G., et al.: 370 Atmospheric observations show accurate reporting and little growth in India's methane emissions, Nature communications, $8,1-7,2017$.

Garny, H. and Randel, W. J.: Transport pathways from the Asian monsoon anticyclone to the stratosphere, Atmospheric Chemistry and Physics, 16, 2703-2718, 2016.

Guha, T., Tiwari, Y. K., Valsala, V., Lin, X., Ramonet, M., Mahajan, A., Datye, A., and Kumar, K. R.: What controls the atmospheric methane seasonal variability over India? Atmospheric Environment, 175, 83-91, 2018.

Han, Y., Revercomb, H., Cromp, M., Gu, D., Johnson, D., Mooney, D., Scott, D., Strow, L., Bingham, G., Borg, L., et al.: Suomi NPP CrIS measurements, sensor data record algorithm, calibration and validation activities, and record data quality, Journal of Geophysical Research: Atmospheres, 118, 12-734, 2013.

Hayashida, S., Ono, A., Yoshizaki, S., Frankenberg, C., Takeuchi, W., and Yan, X.: Methane concentrations over Monsoon Asia as observed by SCIAMACHY: Signals of methane emission from rice cultivation, Remote sensing of environment, 139, $246-256,2013$.

Holl, G., Walker, K. A., Conway, S., Saitoh, N., Boone, C. D., Strong, K., and Drummond, J. R.: Methane cross-validation between three Fourier transform spectrometers: SCISAT ACE-FTS, GOSAT TANSO-FTS, and ground-based FTS measurements in the Canadian high Arctic, Atmospheric Measurement Techniques, 9, 1961-1980, https://doi.org/10.5194/amt-9-1961-2016, https://www.atmos-meas-tech. net/9/1961/2016/, 2016.

Janssens-Maenhout, G., Crippa, M., Guizzardi, D., Muntean, M., Schaaf, E., Dentener, F., Bergamaschi, P., Pagliari, V., Olivier, J. G. J.,Peters, J. A. H. W., van Aardenne, J. A., Monni, S., Doering, U., Petrescu, A. M. R., Solazzo, E., and Oreggioni, G. D.: EDGAR v4.3.2 Global Atlas of the three major greenhouse gas emissions for the period 1970-2012, Earth System Science Data, 11, 9591002, https://doi.org/10.5194/essd-11-959-2019, https://www.earth-syst-sci-data.net/11/959/2019/, 2019.

Kar, J., Deeter, M. N., Fishman, J., Liu, Z., Omar, A., Creilson, J. K., Trepte, C. R., Vaughan, M. A., and Winker, D. M.: Wintertime pollution over the Eastern Indo-Gangetic Plains as observed from MOPITT, CALIPSO and tropospheric ozone residual data, Atmospheric Chemistry and Physics, 10, 12273-12283, https://doi.org/10.5194/acp-10-12273-2010, https://www.atmos-chemphys.net/10/12273/2010/, 2010.

Kavitha, M. and Nair, P. R.: Region-dependent seasonal pattern of methane over Indian region as observed by SCIAMACHY, Atmospheric environment, 131, 316-325, 2016. 
https://doi.org/10.5194/amt-2020-101

Preprint. Discussion started: 13 July 2020

(C) Author(s) 2020. CC BY 4.0 License.
Atmospheric

Measurement

Techniques

Discussions

Kavitha, M. and Nair, P. R.: Satellite-retrieved vertical profiles of methane over the Indian region: impact of synopticscale meteorology, International journal of remote sensing, 40, 5585-5616, 2019.

Kavitha, M., Nair, P. R., Girach, I., Aneesh, S., Sijikumar, S., and Renju, R.: Diurnal and seasonal variations in surface methane at a tropical coastal station: Role of mesoscale meteorology, Science of the Total Environment, 631, 1472-1485, 2018.

Kobayashi, S., Ota, Y., Harada, Y., Ebita, A., Moriya, M., Onoda, H., Onogi, K., Kamahori, H., Kobayashi, C., Endo, H., et al.: The JRA-55 reanalysis: General specifications and basic characteristics, Journal of the Meteorological Society of Japan. Ser. II, 93, 5-48, 2015.

Kuze, A., Suto, H., Nakajima, M., and Hamazaki, T.: Thermal and near infrared sensor for carbon observation Fourier-transform spectrometer on the Greenhouse Gases Observing Satellite for greenhouse gases monitoring, Appl. Opt., 48, 6716-6733, https://doi.org/10.1364/AO.48.006716, http://ao.osa.org/abstract.cfm?URI=ao-48-35-6716, 2009.

Kuze, A., Suto, H., Shiomi, K., Urabe, T., Nakajima, M., Yoshida, J., Kawashima, T., Yamamoto, Y., Kataoka, F., and Buijs, H.: Level 1 algorithms for TANSO on GOSAT: processing and on-orbit calibrations, Atmos. Meas. Tech, 5, 2447-2467, 2012.

Lin, X., Ciais, P., Bousquet, P., Ramonet, M., Yin, Y., Balkanski, Y., Cozic, A., Delmotte, M., Evangeliou, N., Indira, N. K., Locatelli, R.,Peng, S., Piao, S., Saunois, M., Swathi, P. S., Wang, R., Yver-Kwok, C., Tiwari, Y. K., and Zhou, L.: Simulating CH4 and CO 2 over South and East Asia using the zoomed chemistry transport model LMDz-INCA, Atmospheric Chemistry and Physics, 18, 94759497, https://doi.org/10.5194/acp-18-9475-2018, https://www.atmos-chem-phys.net/18/9475/2018/, 2018.

Matsunaga, T., Morino, I., Yoshida, Y., Saito, M., Noda, H., Ohyama, H., Niwa, Y., Yashiro, H., Kamei, A., Kawazoe, F., et al.: Early Results of GOSAT-2 Level 2 Products, in: AGU Fall Meeting 2019, AGU, 2019.

Ohara, T., Akimoto, H., Kurokawa, J., Horii, N., Yamaji, K., Yan, X., and Hayasaka, T.: An Asian emission inventory of anthropogenic emission sources for the period 1980-2020, Atmospheric Chemistry and Physics, 7, 4419-4444, https://doi.org/10.5194/acp-7-44192007, https://www.atmos-chem-phys.net/7/4419/2007/, 2007.

Olsen, K. S., Strong, K., Walker, K. A., Boone, C. D., Raspollini, P., Plieninger, J., Bader, W., Conway, S., Grutter, M., Hannigan, J. W., Hase, F., Jones, N., de Mazière, M., Notholt, J., Schneider, M., Smale, D., Sussmann, R., and Saitoh, N.: Comparison of the GOSAT TANSO-FTS TIR CH4 volume mixing ratio vertical profiles with those measured by ACE-FTS, ESA MIPAS, IMK-IAA MIPAS, and 16 NDACC stations, Atmospheric Measurement Techniques, 10, 3697-3718, https://doi.org/10.5194/amt-10-36972017, https://www.atmos-meas-tech.net/10/3697/2017/, 2017.

Park, M., Randel, W. J., Kinnison, D. E., Garcia, R. R., and Choi, W.: Seasonal variation of methane, water vapor, and nitrogen oxides near the tropopause: Satellite observations and model simulations, Journal of Geophysical Research: Atmospheres, $109,2004$.

Park, M., Randel, W. J., Emmons, L. K., Bernath, P. F., Walker, K. A., and Boone, C. D.: Chemical isolation in the Asian monsoon anticyclone observed in Atmospheric Chemistry Experiment (ACE-FTS) data, Atmospheric Chemistry and Physics, 8, 757-764, https://doi.org/10.5194/acp-8-757-2008, https://www.atmos-chem-phys.net/8/757/2008/, 2008.

Parker, R., Boesch, H., Cogan, A., Fraser, A., Feng, L., Palmer, P. I., Messerschmidt, J., Deutscher, N., Griffith, D. W., Notholt, J., et al.: Methane observations from the Greenhouse Gases Observing SATellite: Comparison to ground-based TCCON data and model calculations, Geophysical Research Letters, 38, 2011.

Patra, P., Krol, M., Montzka, S., Arnold, T., Atlas, E. L., Lintner, B., Stephens, B., Xiang, B., Elkins, J., Fraser, P., et al.: Observational evidence for interhemispheric hydroxyl-radical parity, Nature, 513, 219, 2014.

Patra, P. K., Houweling, S., Krol, M., Bousquet, P., Belikov, D., Bergmann, D., Bian, H., Cameron-Smith, P., Chipperfield, M. P., Corbin, K., Fortems-Cheiney, A., Fraser, A., Gloor, E., Hess, P., Ito, A., Kawa, S. R., Law, R. M., Loh, Z., Maksyutov, S., Meng, L., Palmer, P. I., Prinn, R. G., Rigby, M., Saito, R., and Wilson, C.: TransCom model simulations of $\mathrm{CH}_{4}$ and related species: linking 
transport, surface flux and chemical loss with $\mathrm{CH}_{4}$ variability in the troposphere and lower stratosphere, Atmospheric Chemistry and Physics, 11, 12813-12837, https://doi.org/10.5194/acp-11-12813-2011, https://www.atmos-chem-phys.net/11/12813/2011/, 2011.

Patra, P. K., Canadell, J. G., Houghton, R. A., Piao, S. L., Oh, N.-H., Ciais, P., Manjunath, K. R., Chhabra, A., Wang, T., Bhattacharya,

T., Bousquet, P., Hartman, J., Ito, A., Mayorga, E., Niwa, Y., Raymond, P. A., Sarma, V. V. S. S., and Lasco, R.: The carbon budget of South Asia, Biogeosciences, 10, 513-527, https://doi.org/10.5194/bg-10-513-2013, https://www.biogeosciences.net/10/513/2013/, 2013.

Patra, P. K., Saeki, T., Dlugokencky, E. J., Ishijima, K., Umezawa, T., Ito, A., Aoki, S., Morimoto, S., Kort, E. A., Crotwell, A., et al.: Regional methane emission estimation based on observed atmospheric concentrations (2002-2012), Journal of the Meteorological Society of Japan. Ser. II, 94, 91-113, 2016.

Patra, P. K., Takigawa, M., Watanabe, S., Chandra, N., Ishijima, K., and Yamashita, Y.: Improved Chemical Tracer Simulation by MIROC4. 0-based Atmospheric Chemistry-Transport Model (MIROC4-ACTM), Sola, 14, 91-96, 2018.

Randel, W. J. and Park, M.: Deep convective influence on the Asian summer monsoon anticyclone and associated tracer variability observed with Atmospheric Infrared Sounder (AIRS), Journal of Geophysical Research: Atmospheres, 111, 2006.

Randel, W. J., Park, M., Emmons, L., Kinnison, D., Bernath, P., Walker, K. A., Boone, C., and Pumphrey, H.: Asian monsoon transport of pollution to the stratosphere, Science, 328, 611-613, 2010.

Razavi, A., Clerbaux, C., Wespes, C., Clarisse, L., Hurtmans, D., Payan, S., Camy-Peyret, C., and Coheur, P. F.: Characterization of methane retrievals from the IASI space-borne sounder, Atmospheric Chemistry and Physics, 9, 7889-7899, https://doi.org/10.5194/acp-9-78892009, https://www.atmos-chem-phys.net/9/7889/2009/, 2009.

Ricaud, P., Sič, B., El Amraoui, L., Attié, J.-L., Zbinden, R., Huszar, P., Szopa, S., Parmentier, J., Jaidan, N., Michou, M., Abida, R., Carminati, F., Hauglustaine, D., August, T., Warner, J., Imasu, R., Saitoh, N., and Peuch, V.-H.: Impact of the Asian monsoon anticyclone on the variability of mid-to-upper tropospheric methane above the Mediterranean Basin, Atmos. Chem. Phys., 14, 1142711446, https://doi.org/10.5194/acp-14-11427-2014, 2014.

Rodgers, C. D.: Inverse methods for atmospheric sounding: theory and practice, vol. 2, World scientific, 2000.

Saeki, T., Saito, R., Belikov, D., and Maksyutov, S.: Global high-resolution simulations of $\mathrm{CO}_{2}$ and $\mathrm{CH}_{4}$ using a NIES transport model to produce a priori concentrations for use in satellite data retrievals, Geoscientific Model Development, 6, 81-100, https://doi.org/10.5194/gmd-6-81-2013, https://www.geosci-model-dev.net/6/81/2013/, 2013.

Saito, R., Patra, P. K., Sweeney, C., Machida, T., Krol, M., Houweling, S., Bousquet, P., Agusti-Panareda, A., Belikov, D., Bergmann, D., et al.: TransCom model simulations of methane: Comparison of vertical profiles with aircraft measurements, Journal of 610 Geophysical Research: Atmospheres, 118, 3891-3904, 2013.

Saitoh, N., Touno, M., Hayashida, S., Imasu, R., Shiomi, K., Yokota, T., Yoshida, Y., Machida, T., Matsueda, H., and Sawa, Y.: Comparisons between $\mathrm{XCH} 4$ from GOSAT shortwave and thermal infrared spectra and aircraft $\mathrm{CH} 4$ measurements over Guam, SOLA, 8, 145-149, 2012.

Saitoh, N., Kimoto, S., Sugimura, R., Imasu, R., Kawakami, S., Shiomi, K., Kuze, A., Machida, T., Sawa, Y., and Matsueda, H.: 615 Algorithm update of the GOSAT/TANSO-FTS thermal infrared $\mathrm{CO}_{2}$ product (version 1) and validation of the UTLS CO 2 data using CONTRAIL measurements, Atmospheric Measurement Techniques, 9, 2119-2134, https://doi.org/10.5194/amt-9-2119-2016, https: //www.atmos-meas-tech.net/9/2119/2016/, 2016.

Siddans, R., Knappett, D., Kerridge, B., Waterfall, A., Hurley, J., Latter, B., Boesch, H., and Parker, R.: Global height-resolved methane retrievals from the Infrared Atmospheric Sounding Interferometer (IASI) on MetOp, Atmospheric Measurement Techniques, 10, 4135- 4164, https://doi.org/10.5194/amt-10-4135-2017, https://www.atmos-meas-tech.net/10/4135/2017/, 2017. 
Taylor, S. J. and Letham, B.: Forecasting at scale, The American Statistician, 72, 37-45, 2018.

Walter, B. P., Heimann, M., and Matthews, E.: Modeling modern methane emissions from natural wetlands: 1 . Model description and results, Journal of Geophysical Research: Atmospheres, 106, 34189-34206, 2001.

Watanabe, S., Miura, H., Sekiguchi, M., Nagashima, T., Sudo, K., Emori, S., and Kawamiya, M.: Development of an atmospheric general circulation model for integrated Earth system modeling on the Earth Simulator, J. Earth Simulator, 9, 27-35, 2008.

Webster, P. J., Magana, V. O., Palmer, T., Shukla, J., Tomas, R., Yanai, M., and Yasunari, T.: Monsoons: Processes, predictability, and the prospects for prediction, Journal of Geophysical Research: Oceans, 103, 14451-14510, 1998.

Xiong, X., Barnet, C., Maddy, E., Sweeney, C., Liu, X., Zhou, L., and Goldberg, M.: Characterization and validation of methane products from the Atmospheric Infrared Sounder (AIRS), Journal of Geophysical Research: Biogeosciences, 113, 2008.

630 Xiong, X., Houweling, S., Wei, J., Maddy, E., Sun, F., and Barnet, C.: Methane plume over south Asia during the monsoon season: satellite observation and model simulation, Atmospheric Chemistry and Physics, 9, 783-794, 2009.

Xiong, X., Barnet, C., Maddy, E. S., Gambacorta, A., King, T. S., and Wofsy, S. C.: Mid-upper tropospheric methane retrieval from IASI and its validation, Atmospheric Measurement Techniques, 6, 2255-2265, https://doi.org/10.5194/amt-6-2255-2013, https://www. atmos-meas-tech.net/6/2255/2013/, 2013.

635 Yokota, T., Yoshida, Y., Eguchi, N., Ota, Y., Tanaka, T., Watanabe, H., and Maksyutov, S.: Global concentrations of CO2 and CH4 retrieved from GOSAT: First preliminary results, Sola, 5, 160-163, 2009.

Yoshida, Y., Kikuchi, N., Morino, I., Uchino, O., Oshchepkov, S., Bril, A., Saeki, T., Schutgens, N., Toon, G. C., Wunch, D., Roehl, C. M., Wennberg, P. O., Griffith, D. W. T., Deutscher, N. M., Warneke, T., Notholt, J., Robinson, J., Sherlock, V., Connor, B., Rettinger, M., Sussmann, R., Ahonen, P., Heikkinen, P., Kyrö, E., Mendonca, J., Strong, K., Hase, F., Dohe, S., and Yokota, T.: Improvement of the retrieval algorithm for GOSAT SWIR $\mathrm{XCO}_{2}$ and $\mathrm{XCH}_{4}$ and their validation using TCCON data, Atmospheric Measurement Techniques, 6, 1533-1547, https://doi.org/10.5194/amt-6-1533-2013, https://www.atmos-meas-tech.net/6/1533/2013/, 2013.

Zou, M., Xiong, X., Saitoh, N., Warner, J., Zhang, Y., Chen, L., Weng, F., and Fan, M.: Satellite observation of atmospheric methane: intercomparison between AIRS and GOSAT TANSO-FTS retrievals, Atmospheric Measurement Techniques, 9, 3567-3576, 2016. 